\title{
Alternatives to Animal Experimentation in Basic Research
}

\author{
Franz P. Gruber ${ }^{1}$ and Thomas Hartung ${ }^{2}$ \\ ${ }^{1}$ FFVFF, CH-Zurich; ${ }^{2}$ ECVAM, EU JRC, I-Ispra and University of D-Konstanz*
}

\section{Content}

1 Introduction

2 Basic Research, what does the term mean?

2.1 Definitions and dimensions

2.2 Delineation from the applied sciences

2.3 Alternative methods need to be funded

3 Obstacles and opportunities for alternative methods in basic research

3.1 Definitions

3.2 Publication of alternatives in scientific journals

3.3 What drives and what hampers the progress of alternatives?

3.3.1 Relevance

3.3.2 Availability

3.3.3 Visibility

3.3.4 Awareness

3.4 Advantages and disadvantages of in vitro compared to in vivo models

3.4.1 Advantages of in vivo models

3.4.2 Disadvantages of in vivo models

3.4.3 Advantages of in vitro models

3.4.4 Disadvantages of in vitro models

4 Examples of published alternative methods in basic research

4.1 In vivo alternatives

4.1.1 The incubated chicken egg as an alternative

4.1.2 Transgenic animal models

4.1.3 Refinement during procedures, e.g. anaesthetics and analgesics

4.1.4 Refinement during procedures, e.g. humane endpoints

4.1.5 Refinement during procedures, e.g. computertomographic models

4.1.6 Enrichment in animal keeping, considering the needs of behavioural biology

\section{Summary}

In contrast to animal testing required by law to guarantee minimum safety standards for the licensing of drugs and chemicals, there are no regulations in basic research forcing scientists to perform animal tests. By (usually) free choice, questions are posed and hypotheses are examined which, in many cases, can only be answered by means of animal tests. Just as easily, different questions could be asked or different hypotheses could be examined which do not require animal tests. The only criterion for the choice

\footnotetext{
Received 9 October 2002; received in final form and accepted for publication 28 October 2004

* The texts and suggestions represent the privat opinions of the authors
}

4.2 Isolated organs as models in basic research

4.2.1 Animal tissues and organs in research

4.2.2 Human tissues and organs in research

4.3 Cell culture models

4.3.1 The possibilities of hepatocyte cultures

4.3.2 Cell cultures in cancer research

4.3.3 Stem cell methods

4.3.4 Genetically modified cells

4.3.5 Artificial membranes

4.4 3R principles in antibody production

4.4.1 A success story: The in vitro production of monoclonal antibodies

4.4.2 Alternatives to come: The recombinant antibody families

4.4.3 In the meantime: Refinement - the IgY antibody

4.4.4 Alternative adjuvants

4.5 In vitro techniques in parasitology

4.6 In silico alternatives

5 Further developments and resources for information systems on alternatives

6 Discussion

6.1 Does freedom of science hamper 3R methods?

6.2 Animal welfare in the constitutional law

6.3 Importance of representative statistics on animal experimentation

7 Solutions, medium and long-term development

7.1 Harmonisation

7.2 Increasing the quality of in vitro methods

7.3 Promoting the use of animal-free methods

7.4 The pipeline

7.5 Education of a topic is its relevance which cannot necessarily be judged in the short-term. Thus, it is up to the individual scientist to judge what is worth studying and therefore worth animal consumption. The educated mind will consider ethical aspects of this choice. However, on the other hand, this decision is largely influenced by questions of efficacy or (in a negative sense) by the obstacles posed to an animal consuming approach. Here, peer review and general attitude will strongly influence the methodology chosen. Availability and awareness of adequate in vitro techniques represent the prerequisites for the use of alternative methods.

The least one can do in basic research is to avoid tests which cause severe suffering to animals, as is required in Switzerland 
and other European countries by binding ethical principles and guidelines. The increasing standard of approval and control procedures has improved the situation over the years.

There are many examples of successful alternative methods in basic research. But, the application of such methods is in most cases limited to the laboratories in which they were developed, calling for technology transfer. Exceptions are procedures that are used worldwide, like the production of monoclonal antibodies, which instead of using the ascites mouse can also be performed in vitro with some good will. In these cases, commercialisation of the techniques has aided their spread within the scientific community. Sadly, many methods, even if published in the scientific literature, are little standardised and reproducible. The suggestion is put forward that publicly accessible databases should make available more detailed descriptions of methodologies. Due to limitations in space, many scientific journals cannot publish detailed methodological descriptions. However, nowadays a supplementary central deposit of methods could easily be linked to the respective article.

In numerous cases though, there is simply a lack of will to change procedures to methods without animal tests or to pose questions differently in order to avoid the use of animals or to reduce their number or, at least, to reduce stress. In other cases, researchers are simply not aware of the limitations of the animal experiment as such. A thorough review of the validity of critical animal experiments should be carried out and made available publicly. For example, many animal experiments are dramatically "underpowered", i.e. carried out with groups that are too small to allow conclusions to be drawn from the outcome. This stands in marked contrast to in vitro experiments where replicate experiments usually represent no major problem.

Since in vitro models are generally more prone to artefacts due to the numerous variables, e.g. of cell culture, the key requirement for their application is their validation and quality control. Guided by the experience from validation studies for alternative methods in toxicology, concepts of a Good Cell Culture Practice $(G C C P)$ are currently being developed which aim to define minimum quality standards for in vitro techniques. This initiative aiming to increase quality must be complemented by a concept to systematically assess the relevance of the tests in order to finally achieve an evidence-based biomedical research.

A change in this direction is only possible if those public funds, which were previously assigned predominantly to alternatives to the animal tests required by law, are now channelled increasingly into developing those for basic research. A financial incentive is necessary to change procedures in basic research to animal free procedures. Ethical considerations alone will bring little movement or change. It is unacceptable that, while numbers of animal tests decrease in development and notification of drugs and chemicals, they are increasing in basic research. Due to the central role of publishing scientific results, the key options for control are the respective rules of journals for the acceptance of articles. By demanding certain standards in the instructions for authors, e.g. of quality (GCCP), relevance and in case of animal experiments proof that no alternative is available, pressure could be dramatically increased. It is suggested to hold a consensus conference of journals in the life sciences on this topic.
Zusammenfassung: Alternativen zu Tierexperimenten in der Grundlagenforschung

Anders als bei gesetzlich vorgeschriebenen Tierversuchen, die einen Mindeststandard an Sicherheit bei der Zulassung von Arzneimitteln und Chemikalien sichern sollen, gibt es in der Grundlagenforschung keinerlei Vorschriften, die von Wissenschaftlern den Einsatz von Tierversuchen verlangen würden.

Es werden bestimmte Fragen gestellt, Hypothesen geprüft, die sich vielfach nur mit Tierversuchen beantworten lassen. Man könnte aber genauso gut andere Fragen stellen und andere Hypothesen prüfen, zu deren Beantwortung keine Tierversuche nötig sind. Das einzige Kriterium für die Wahl ist die Relevanz, die nicht unbedingt kurzfristig vorausgesagt werden kann. Was man untersuchen sollte und ob dieses Ziel den Einsatz von Tieren rechtfertigt, wird also letztlich individuell vom einzelnen Forscher entschieden. Dass dabei ethische Überlegungen eine Rolle spielen sollten wird beim Bildungsstand der Wissenschaftler vorausgesetzt. Die Entscheidung wird aber auch von Nützlichkeitserwägungen beeinflusst und - negativ - von den Hindernissen, die beim geplanten Einsatz von Versuchstieren überwunden werden müssen. Die Begutachtungsverfahren von Wissenschaftsjournalen und der allgemeine Konsens beeinflussen dabei die Wahl der Methode erheblich. Vorhandensein, Zugriff und Kenntnisse von ihrer Existenz sind Grundvoraussetzungen für den Gebrauch von Alternativmethoden. Man kann in der Grundlagenforschung zumindest auf solche Versuche verzichten, die den Tieren schwerste Leiden zufügen, so wie es die in der Schweiz und in anderen europäischen Ländern verbindlichen ethischen Grundsätze und Richtlinien verlangen. Zudem verbesserte sich die Situation im Verlauf der Jahre durch die ständige Erhöhung der Standards bei der Bewilligung und Kontrolle von Tierversuchen.

Es gibt viele Beispiele für erfolgreiche Alternativmethoden auch in der Grundlagenforschung. Doch deren Anwendung beschränkt sich meist gerade auf das Labor, in dem sie entwickelt wurden. Ausnahmen sind Verfahren, die weltweit üblich waren, wie die Herstellung monoklonaler Antikörper in der Aszitesmaus, ein Verfahren, das sich mit einigem guten Willen auch in vitro durchführen lässt. In diesen Fällen hat die Kommerzialisierung der Methodik stark zu ihrer Verbreitung in der Wissenschaftsgemeinschaft beigetragen. Dagegen sind viele Alternativmethoden, obwohl in wissenschaftlichen Zeitschriften publiziert, noch immer kaum standardisiert und reproduzierbar. Es wird vorgeschlagen, dass öffentlich zugängliche Datenbanken detailliertere Beschreibungen der Methoden enthalten. Aus Platzmangel können viele Wissenschaftsjournale diese Leistung nicht bieten. Heutzutage sollte es jedoch möglich sein, aus einer zentralen Datenbank heraus jeden Artikel mit der entsprechenden Methode zu verlinken.

Bei nicht wenigen Versuchen fehlt es aber schlicht am Willen, sie durch tierversuchsfreie Methoden abzulösen oder die Frage anders zu stellen, um die Verwendung von Tieren zu vermeiden, stark zu reduzieren oder wenigstens in ihrer Belastung zu vermindern. In anderen Fällen sind sich die Wissenschaftler der begrenzten Aussagekraft der Tierexperimente als solche einfach nicht bewusst. Es müsste eine sorgfältig durchgeführte Studie zur Validität von kritischen tierexperimentellen Studien 
durchgeführt und der Öffentlichkeit zugänglich gemacht werden. Manche Versuche sind schlicht zu klein angelegt, d.h. sie wurden mit so wenigen Tieren durchgeführt, dass bestimmte Aussagen einfach nicht gemacht werden können. In vitro ergeben sich solche Probleme so gut wie nie, da Versuchswiederholungen üblicherweise keine größeren Probleme bereiten.

In vitro Methoden begünstigen wegen der hohen Zahl an Variablen häufig Artefakte, vor allem bei Zellkulturen. Um sie anwenden zu können sind Validierung und Qualitätskontrolle unabdingbar. Angeregt durch die Erfahrungen, die bei toxikologischen Validierungsstudien gemacht wurden, werden z.Z. Konzepte für eine Gute Zellkulturpraxis entwickelt (GCCP), um wenigstens einen minimalen Standard bei in vitro Techniken gewährleisten zu können. Diese qualitätsorientierte Initiative muss durch ein Konzept ergänzt werden, das systematisch die Relevanz von Versuchen erfasst, um letztlich zu einer Evidenzbasierten biomedizinischen Forschung zu gelangen.

Eine Veränderung dieser Situation kann es nur geben, wenn öfentliche Fördermittel, mit denen bisher hauptsächlich
Versuche zum Ersatz von gesetzlich vorgeschriebenen Tierversuchen finanziert wurden, vermehrt für solche in der Grundlagenforschung fliessen. Es muss auch einen finanziellen Anreiz. geben, Verfahren in der Grundlagenforschung in tierversuchsfreie umzustellen; einzig aus ethischen Überlegungen heraus wird sich nur langsam etwas bewegen. Es ist aber nicht hinzunehmen, dass bei einer ständigen Verminderung von Tierversuchen zur Zulassung von Arzneimitteln und Chemikalien gleichzeitig die Tierzahlen in der Grundlagenforschung ansteigen.

Da die Publikation wissenschaftlicher Ergebnisse eine zentrale Rolle spielt, steht und fällt der Zugang zu jeder Kontrolle mit den Richtlinien, die sich Journale für die Publikation von Ergebnissen geben. Mit der Forderung, in den Richtlinien für Autorinnen und Autoren gewisse Standards zu verankern, z.B der Qualität (GCCP), der Relevanz und im Fall von Tierversuchen der Nachweis, dass keine Alternative verfügbar ist, könnte der Qualitätsdruck dramatisch erhöht werden. Es wird vorgeschlagen, zu diesem Zweck eine Konsensus-Konferenz der Journale in den Biowissenschaften abzuhalten.

Keywords: animal testing alternatives, $3 R$ methods, basic research, availability, awareness, relevance, publishing rules

\section{Introduction}

Despite the worldwide advancement of the $3 \mathrm{R}$ principle, the largest funding body in German-speaking countries, i.e. the Deutsche Forschungsgemeinschaft (DFG, i.e. the German Research Council) has not made use of this term up until the year 2001. In a number of memorandums, statements and communications about the situation of animal experimentation, the term 3R cannot be found (DFG 1971, 1981, 1991, 1993, 1996). In the meantime the ESF (European Science Foundation), the council of European Scientific Societies in basic research, to which the DFG belongs, published a new codex on the $9^{\text {th }}$ of September 2000, in which the national societies are called on explicitly to accept and promote the $3 \mathrm{R}$ principle. Usually, it takes some years until such recommendations are put into practice. The DFG is called to adopt these principles as soon as possible and include them in the Rules for funding.

Over the last three years the number of animals consumed in basic research has been increasing in Germany, Switzerland and most probably also in other industrialised countries. Therefore, it is very urgent to increase the consideration of $3 \mathrm{R}$ aspects in basic research.

This study aims to illustrate the lacking flow of information, which hampers the establishment of the $3 \mathrm{R}$ principle in basic research. Such a review cannot be comprehensive or even representative, but wants to give examples and highlight key aspects. The authors want to stress the promise and merits of the 3R principle of Russel and Burch (1959) as a practical, feasible compromise also for basic research. The definition of the $3 \mathrm{R}$ concept is still the best way to practice humane science and the definition of alternative methods is still the same as in 1959: "All procedures which can completely replace the need for animal experiments, reduce the numbers of animals required, or diminish the amount of pain and distress suffered by animals in meeting the essential needs of man and other animals." (Balls et al., 1995).

\section{Basic Research, what does the term mean?}

\subsection{Definitions and dimensions}

The Deutsche Forschungsgemeinschaft (DFG, 1993) defines basic research, i.e. science not aiming for immediate application of results, as follows (literal translation): "This research springs from the human thirst for knowledge, it satisfies our desire to understand the world in which we live and is a characteristic trait of the species Homo sapiens. The results of this scientific search for knowledge may be used - or misused - to very different ends. It will not be suppressed."

The absolute numbers of consumed animals are increasing in basic science. Table 1 and Figure 1 show this trend for Switzerland. The proportion of animals used for basic research has increased between 1994 to 2000 from $14 \%$ to $29 \%$. In total, however, this increase has not (yet) tipped the overall trend to decreasing animal numbers in Switzerland, though in the canton Zurich, which is strong in the field of research, this is already the case. In Germany, the pro- 
portion of animals used in basic research increased from $14 \%$ in 1991 to $28 \%$ in 1999 (Tab. 2 and Fig. 2). This increase already resulted in an increase in the total animal use, which will continue according to experts (BMBF symposium Munich-Neuherberg, May 2002). The European statistics offer detailed numbers for 1999. According to these numbers, the proportion of animal use in basic research in Europe is $30 \%$ (Fig. 3).

The underlying reason for increasing animal use can be deduced from the Swiss statistics in the years 1992-2003, i.e. transgenic animals, mainly mice, which added on more than 90,000 animals in Switzerland in 2000 (Tab. 1). This trend appears to flatten now.
In principle, animal experiments in basic research can be divided into those that deal with the health and well-being of humans (medical basic science) and those which serve the general understanding of nature (biological basic science). However, these fields cannot be completely separated, as biological science also deals with experiments aimed at understanding the healthy or sick human body and behaviour. A scale could be devised demonstrating the immediacy results from scientific research might have for human benefit.

Bateson's cube (Fig. 4) is a typical example for such a scale of immediacy (Bateson, 1986). It has the advantage that it reflects the problem of felling a deci-

Tab. 1: Development of animal numbers in Switzerland

\begin{tabular}{|l|l|l|l|l|l|l|l|l|}
\hline & 1996 & 1997 & 1998 & 1999 & 2000 & 2001 & 2002 & 2003 \\
\hline $\begin{array}{l}\text { total number } \\
\text { of animals }\end{array}$ & 509,755 & 492,186 & 452,535 & 445,682 & 423,127 & 446,654 & 485,969 & 475,455 \\
\hline $\begin{array}{l}\text { In basic } \\
\text { research }\end{array}$ & 129,016 & 143,310 & 117,426 & 124,118 & 123,102 & 115,717 & 136,952 & 147,422 \\
\hline $\begin{array}{l}\% \text { animals } \\
\text { in basic res. }\end{array}$ & 25,3 & 29,1 & 25,9 & 27,8 & 29,1 & 25,9 & 28,2 & 31,0 \\
\hline $\begin{array}{l}\text { transgenic } \\
\text { animals* }\end{array}$ & n.d. & 42,750 & 52,500 & 56,250 & 59,250 & 60,000 & 67,945 & 63500 \\
\hline $\begin{array}{l}\% \text { animals } \\
\text { transgenic }\end{array}$ & n.d. & 8.7 & 11.6 & 12.6 & 14.0 & 13.4 & 14.0 & 13.4 \\
\hline
\end{tabular}

* estimated from diagramm 3.3 in

www.bvet.admin.ch/tierschutz/TV-Statistik/Jasta-03/D/33/Grafik.html

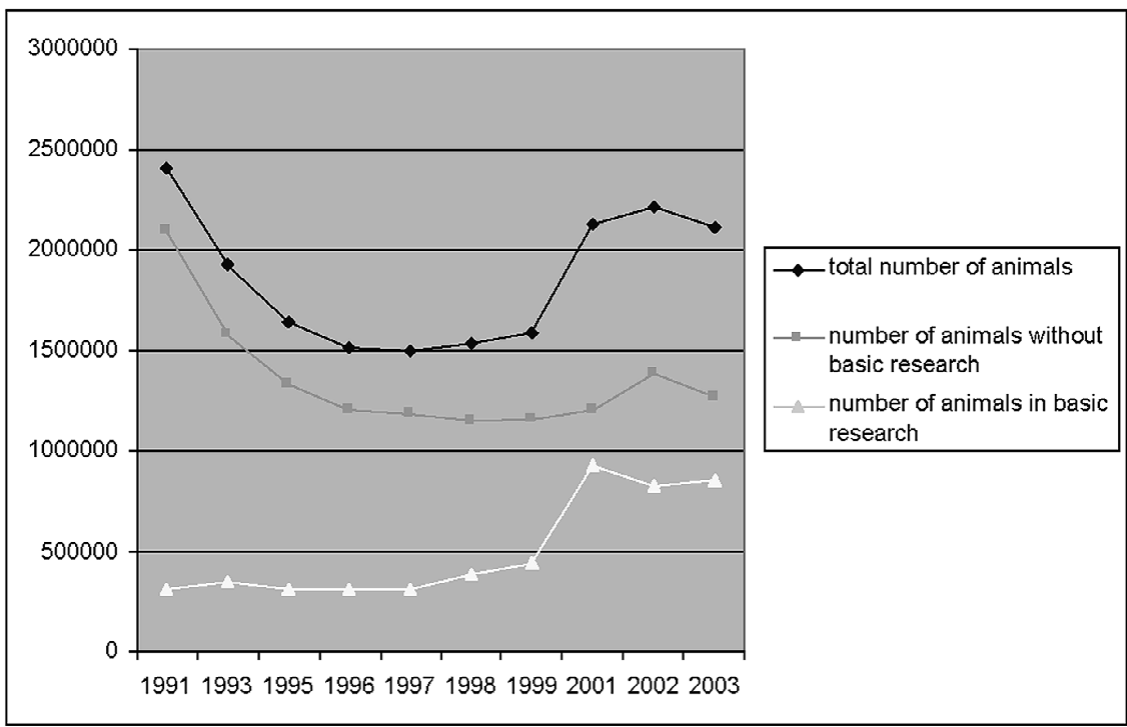

Fig. 1: Development of animal numbers in Switzerland

sion as a problem of weighing out competing interests. It uses three criteria to come to a decision: (1) scientific quality of the research project, (2) the probability that the research project will lead to important biomedical results and (3) the degree of stress and suffering of the animals used. There are a number of severity catalogues by means of which the stress experienced by the animals can be gauged before and after the experiment. The most commonly used such catalogue in the German-speaking countries (prospective and retrospective) was compiled by the Swiss BVET (1994).

In principle, even the most stressful procedures may be carried out in basic research, as the German animal protection law states, "Experiments on vertebrates, which cause significant long lasting or repeated pain or suffering, may only be carried out if the results which are aimed at allow the assumption that they will be of particular importance for considerable needs of humans or animals including the solving of scientific problems." The solving of scientific problems, even if no application that would benefit humans can be recognised, is generally imbued with particular importance. Therefore, considerable burdens must be born, because this is considered among the essential needs of humans and animals. The EU directive 86/609/EEC also allows animal experiments for scientific research without requiring a biomedical background. Until now, limitations in basic research have only emerged for the use of primates. In 2002, the Scientific Steering Committee of the EU (s. ALTEX 19, 89) for research reduced the areas in which primates may still be used to the development of medications and vaccines for the prevention and healing of diseases such as AIDS, BSE, malaria and influenza, i.e. all areas in which direct medical advances are implemented. Pure basic research is not represented in this list. However, of course, this list only has an advisory, not a compulsory character.

In Switzerland, funding of projects by the Nationalfonds (the Swiss Research Council similar to Deutsche Forschungsgemeinschaft) requires adherence of the scientists to the ethical principles and guidelines first established in 1994 and 
amendments published in ALTEX and further journals (SAMW and SANW, 1996). Paragraph 4.6 of these guidelines states that in case of unbearable suffering of animals the experiments must be declined. In addition, animal experiments, which do not concur with these guidelines may not be exported to other countries.

While SOPs (standard operation procedures) are mandatory for animal experiments required by laws and regulations, the variability of the methodology used in basic research is great. It has not even been possible to set up uniform protocols for the production of antibodies by immunisation of animals. The spectrum of alternative methods must be appropriately manifold to establish the $3 \mathrm{R}$ principles in basic research.

\subsection{Delineation from the applied sciences}

In the applied sciences the regulatory acceptance of alternative methods usually undergoes a stringent series of tests, from within-laboratory to between-laboratory to international comparisons and finally to the drafting of monographs in pharmacopoeias (drugs) or OECD guidelines (chemicals). Such a series of validation tests is not the norm in basic research. Every scientist can believe the results of his colleagues or not. He can try out the
Tab. 2: Development of animal numbers in Germany

\begin{tabular}{|l|c|l|l|l|l|l|l|l|}
\hline & 1996 & 1997 & 1998 & 1999 & 2000 & 2001 & 2002 & 2003 \\
\hline $\begin{array}{l}\text { total number } \\
\text { of animals }\end{array}$ & $1,509,619$ & $1,495,741$ & $1,532,572$ & $1,591,394$ & $1,825,215$ & $2,126,561$ & $2,212,376$ & $2,112,341$ \\
\hline $\begin{array}{l}\text { In basic } \\
\text { research }\end{array}$ & 308,569 & 314,782 & 385,993 & 438,017 & 679,026 & 926,294 & 826,729 & 850,710 \\
\hline $\begin{array}{l}\% \text { animals } \\
\text { in basic res. }\end{array}$ & 20.4 & 21.0 & 25.2 & 27.5 & 29.1 & 25.9 & 37.4 & 40.3 \\
\hline $\begin{array}{l}\text { transgenic } \\
\text { animals }\end{array}$ & & & & & 156,876 & 204,386 & 222,212 & 254,155 \\
\hline $\begin{array}{l}\% \text { animals } \\
\text { transgenic }\end{array}$ & & & & & 8.6 & 9.4 & 10.0 & 12.0 \\
\hline
\end{tabular}



Fig. 2: Development of animal numbers in Germany

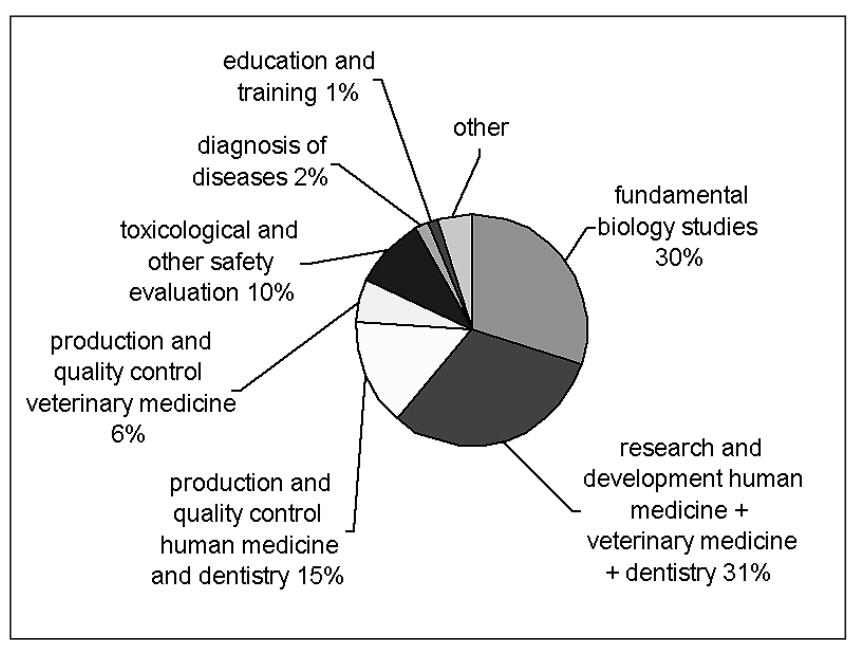

Fig. 3: Distribution of animal numbers in the EU in 1999

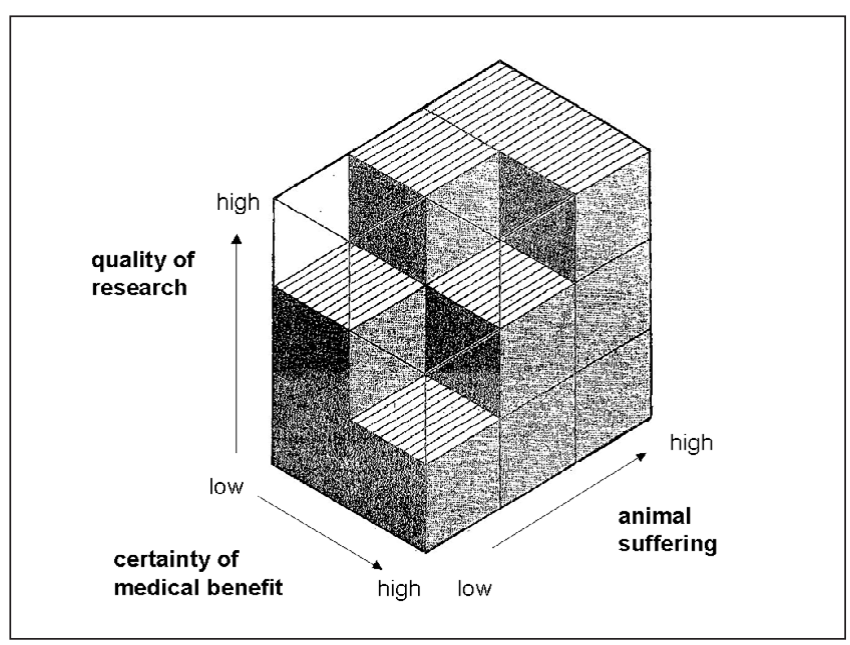

Fig. 4: Graph according to Bateson (1986). Quality of research, certainty of benefit and animal suffering should be in a balanced relation. When a research proposal falls into the opaque part of the cube, the experimental work should not be done 
alternative method or not. If the alternative does not work first time round, nobody forces him to try again. The authorities who must give permission for the animal experiments in basic research usually have no overview of the existing alternatives. They must believe the statement of the scientist who often denies the existence of alternatives even if some do exist.

It is alarming that animal experiments in medical research apparently often do not lead to major results: Lindl et al. (2001) report a review of 51 studies based on animal experiments that were proposed in the years 1991-1993 at a German university. First, the declared aims of the proposals were evaluated against the applicants' own statements with regard to the pain suffered by the animals. Secondly, it was evaluated whether these proposals led to relevant publications in the scientific literature and whether these results led to improvements in the respective fields of research. A ranking was established from zero (no results were published within 8 years) to three (all the proposed goals were effectively reached and published). Only one third of the proposals reached grade three, and for nearly $40 \%$ of the proposals either no relevant publications were found or these proposals were never set into practice. Distinction of the research in applied and basic research revealed that basic research per se results in a much higher percentage of grade three (over 56\%). The reason for this might be that basic research always has something to report, satisfying a scientific journal since applicability need not be proven. Noteworthy, as a side aspect it was found that in $60 \%$ of the studies the scientists underestimated the actual level of suffering of the animals.

Table 3 attempts to demonstrate the differences between applied, medical and biological basic research.

\subsection{Alternative methods need to be funded}

Basic science strongly depends on public support since it has no immediate application in medicine. No company would easily invest in such projects. Thus, basic research very strongly depends on public consensus, since in the long term no society will finance projects, which are not fully in line with law or morale. A prominent example is the current discussion on stem cell research. Similar discussions are needed when techniques, which raise animal consumption, are again increasingly applied in basic research.

The German Ministry of Research is probably the largest national supporter of alternative methods worldwide. From 1980-2000 82 million $€$ were spent for this purpose. In comparison, the German Research Council (Deutsche Forschungsgemeinschaft, DFB) alone spent 456.8 million $€$ in 2002 on biomedical research (Bundesbericht Forschung, 2004)

A study evaluating projects on alternatives covering a total of 37 million $€$ of funding was reported some years ago (Gruber et al., 1996): According to their research subjects, the projects were clas- sified by the following categories: Reduction of distress or of the number of laboratory animals used in an experiment $(10.6 \%)$; reduction of the number of animals by performing an animal-free method before the animal test (43.1\%), replacement of animal test by an animalfree method (18.6\%), basic research $(18.1 \%)$, promotion of its acceptance by optimisation of an animal-free method (6.2\%) and validation of an animal-free method (3.3\%). It was remarkable that only $18.1 \%$ of the budget was given to basic research. In 2000 a workshop, which was organised by the ministry in Bad Godesberg, aimed to develop new guidelines for funding of research on alternatives with the aim to intensify support for basic research. The follow-up workshop in 2002 in Munich especially addressed approaches to promote the $3 \mathrm{R}$ principle in research with transgenic animals. This technology is responsible for most of the increases in animal numbers in basic research. The same ministry has thus sponsored reduction of animal use and techniques leading to increased consumption at the same time.

But exactly those disciplines, which contribute most to increasing animal numbers, discuss replacement least. Apparently, the scientific results promised by genetically engineered animals are too tempting. Disappointing for animal welfare activists, it must be expected that animal numbers will - not dramatically, but steadily - increase over the next few years. Hopefully, this will not lead to new clashes between science and society.

Tab. 3: 3R relevant differences between applied regulatory, medical and biological basic research

\begin{tabular}{|c|c|c|c|}
\hline & regulatory testing & medical applied research & basic research \\
\hline initiation/reason of science & legal aspects & $\begin{array}{l}\text { orientated on sickness, } \\
\text { effects and side effects } \\
\text { of drugs to human beings } \\
\text { and animals }\end{array}$ & proof of scientific hypotheses \\
\hline type of science & standard operating procedures & $\begin{array}{l}\text { efficiency of e.g. agent } \\
\text { discovery }\end{array}$ & exploratory \\
\hline quality control & prevalidation, validation & evaluation & peer review in journals \\
\hline dispersion of results & report to authorities & $\begin{array}{l}\text { limited since proprietary } \\
\text { products }\end{array}$ & publication \\
\hline consequences & $\begin{array}{l}\text { permission or non-permission } \\
\text { by authorities }\end{array}$ & $\begin{array}{l}\text { alteration of national and } \\
\text { international pharmacopoeias }\end{array}$ & $\begin{array}{l}\text { acceptance or rejection of } \\
\text { new hypotheses }\end{array}$ \\
\hline
\end{tabular}


The portion of funding basic research receives from diverse institutions in German-speaking countries is displayed in Table 4.

The proportion of basic research funded by these institutions varies greatly. This insight should lead to the realisation that increased funding from non-governmental funding organisations should flow into $3 \mathrm{R}$ relevant basic research. Minimising statutory animal experiments with $3 \mathrm{R}$ methods is the obligation of the institutions of state, which require these experiments. Basic research does harbour a higher risk of investing money in unsuccessful projects, but that is a risk one must carry: basic research is often high risk and success can never be guaranteed.

\section{Obstacles and opportunities for alternative methods in basic research}

\subsection{Definitions of test systems used as alternatives}

First it is necessary to define what we mean by alternative methods or in vitro methods and related terms:

- In vitro methods comprise every type of experiment in the life sciences, which makes use of living material but does not involve animals or humans except as donors of tissue or cells. The term "ex vivo" is usually reserved for the pretreatment of the donor before tissue sampling. Much confusion is caused by the fact that molecular biologists often use "in vivo" when talking about cells in contrast to the cell-free systems they usually work with. It would be very helpful to coin a distinction that is generally accepted.

- In vitro tests deliver a defined result, i.e. they measure or classify. In contrast, a method could also comprise the production of materials (e.g. monoclonal antibodies) or descriptive approaches (e.g. histology). The test result may be qualitative (e.g. mutagenic or not), semiquantitative (e.g. no, weak, intermediate or strong irritant) or quantitative (e.g. a score, a percentage or any number summarising the result).

- In vitro technologies refer to methodologies, which enable the establishment of in vitro methods. For example perfusion culture, immortalisation of cells or precision-cut tissue slices represent techniques which enable setting up in vitro methods or tests.

- The term animal-free would imply that no animals are consumed, not even as donors of cells or tissue.

- A filter test is a test which functions as a preliminary test to sort substances, e.g. substances to be tested in vivo, because the result is foreseeable (e.g. a simple $\mathrm{pH}$ test before applying a substance into

Tab. 4: Portion of funding alternative methods in basic research from diverse institutions in German speaking countries (actual status given as number of projects in 2000)

\begin{tabular}{|l|l|l|l|l|}
\hline & $\begin{array}{l}\text { basic } \\
\text { research }\end{array}$ & $\begin{array}{l}\text { applied } \\
\text { research }\end{array}$ & $\begin{array}{l}\text { projects to } \\
\text { spread } \\
\text { 3R knowledge }\end{array}$ & $\begin{array}{l}\text { percentage of } \\
\text { projectsin basic } \\
\text { research }\end{array}$ \\
\hline D-BMB & 23 & 19 & 0 & 55 \\
\hline Ö-BMB & 12 & 1 & 0 & 92 \\
\hline B.-W.MW & 6 & 1 & 0 & 86 \\
\hline ZEBET $^{4}$ & 14 & 4 & 0 & 78 \\
\hline SET $^{5}$ & 8 & 3 & 6 & 47 \\
\hline CH-3R $^{6}$ & 13 & 6 & 0 & 68 \\
\hline FFVFF & 1 & 0 & 4 & 20 \\
\hline
\end{tabular}

${ }^{1}$ German Ministry of Research,

2 Austrian Ministry of Research,

3 Baden-Württemberg Ministry of Research,

${ }^{4}$ German Center for Documentation and Evaluation of Alternative Methods to Animal

5 Experiments,

${ }^{6}$ Swiss Foundation Research 3R,

${ }^{7}$ Swiss Foundation for Animal Free Research

the rabbit eye), thereby reducing the number of animal experiments.

- An alternative is a method or test, which replaces, reduces or refines an animal experiment. Therefore, the respective in vivo experiment must be clearly defined. An alternative can even be another in vivo experiment, in which less animals are consumed, there is less harm to the animals or e.g. primate use is replaced by use of "lower" animals.

- A validated alternative is a test which has undergone the procedure of validation, which is best defined by the ECVAM criteria (Balls and Karcher, 1995). This will only be required rarely in basic research. Noteworthy, only tests not methods can be validated, since only these allow biometrical analysis. The aim of validation is to establish the reproducibility and the relevance of a test. This usually requires a collaborative study to assess interlaboratory variability and a comparison with (historic) in vivo data. The structured process of validation includes the standardisation of the test and its biometrical analysis. Finally, a prediction model has to be established which converts the result of the alternative (e.g. $40 \%$ of the cells killed) to the estimated in vivo result (e.g. score of the Draize rabbit eye test). This step has proven to be most difficult because it can be based on correlation only, which is strongly biased by the selection of examples the correlation is based on: If the alternative is established for one class of substances, another prediction model might be required for the next class of substances.

- An approved or accepted alternative refers to a method, which is accepted by an authority formerly demanding (by law, guidelines or simply practice) an animal experiment as an in vitro substitute.

\subsection{Publication of alternatives in scientific journals}

There is a lot of confusion on the use of the different terms. Authors of papers published in the relevant journals for alternatives (e.g. ALTEX, ATLA, In vitro Toxicology, Toxicology in vitro, etc.) often claim to have developed an alternative method, when they have actually established an in vitro model. If the term 
alternative referred to anything you can do without using animals, it would include research in history of art. Reviewers and editors should not accept such phrasings. The term "alternative" should be reserved for in vitro or in silico models, which aim to replace or reduce a clearly defined in vivo experiment. Similarly, following the evaluation of their models, authors tend to attribute validity to their method or even term it validated. It is very important to reserve the term "validated alternative" for those methods, which have undergone a thorough validation study, usually in form of a collaborative study, with a positive outcome.

If these distinctions are not applied carefully, confusion and too high expectations of users and the public are the result, which in the long-term turn into disappointment and harm the field of alternatives. Too often expectations are raised that animals are spared by a new method, without considering the prolonged and demanding procedure of validation and acceptance. The unjustified claims are understandable: they are made to satisfy the demands of funding bodies, journals or award applications. It is the reviewers' duty to sort out what has really been achieved.

It should also be mentioned that even purely methodological basic research, e.g. to increase the reliability of cell cultures, can also represent a contribution to $3 \mathrm{R}$ research. It can increase the acceptance greatly, when such methods are employed for the replacement of an animal experiment.

\subsection{What drives and what hampers the progress of alternatives?}

In principle basic research is free, free to choose topics and free to choose adequate methods to answer its questions. It is therefore important to analyse what is driving and what is hampering the use of in vitro techniques instead of in vivo models.

\subsubsection{Relevance}

Judgement of the relevance of a given model by the individual scientist and his/her peers is most crucial: The aim is not to perform a certain technique but to solve a certain problem. Only occasionally the availability of a certain method, i.e. already established expertise, will prompt continuation and determine the subject to be studied. To interrupt such cycles, i.e. to avoid that a scientist with expertise in vivo simply continues to work in vivo because this is his/her speciality, it is necessary that justifications for in vivo work must nowadays be given to ethical review boards on a regular basis. This makes the scientist argue (and hopefully also question) his/her approach and the need for the animal experiment.

Animal experiments are often overestimated with regard to their relevance. Firstly, species-dependent differences to the human situation are often overlooked or neglected. Secondly, animal use has declined considerably due to the fact that inbred strains reduce variation (as if only identical twins were used in a clinical study), but the resulting limitation in extrapolation of results is usually neglected. Thirdly, most animal experiments were never properly validated. Fourth, there is considerable underreporting of pitfalls and limitations of a given animal experiment (no one dares to write that the model he/she is working with fails, no journal is interested in negative or, even worse, ambiguous results). Fifth, there is a dangerous trend towards reporting only the best of repetitive experiments or even to leaving out those that "did not work". Sixth, most animal experiments are strongly underpowered, i.e. the number of animals per group is not adequate for the inherent variability; proper biometrical analysis shows that conclusions can often not be drawn and sub-selection of results and inappropriate statistics are run (non-justified assumption of Gaussian distribution, comparison of two groups only where several groups were run and ANOVA is required, employment of prospective tests for retrospective analysis, non-justified assumption of one-sided test situations or not taking into account multiple testing); the same limitations hold true for many in vitro tests, though here replications are usually not limiting.

The obvious consequences of this line of reasoning are threefold: (1) the limitations of in vivo models must be made clear e.g. by re-assessment or direct comparison with in vitro tests and clinical data; (2) information on the shortcomings of in vivo models must be made publicly available, e.g. as databases; (3) the advantage of easier validation and quality assurance in vitro should be leveraged to ensure a superiority of in vitro approaches. Here, the importance of initiatives for Good Cell Culture Practice (GCCP) becomes evident (see below).

\subsubsection{Availability}

In contrast to most animal experiments, most in vitro techniques require relatively sophisticated equipment. While many universities offer facilities to carry out animal experiments, a common infrastructure for in vitro work is rare.

\subsubsection{Visibility}

The various databases developed over the last decade have made available information on alternatives (Janusch et al., 1997; Janusch-Roi et al., 2000; Grune et al., 2000). However, mere citations and the respective descriptions in the published articles are usually too brief to allow the adoption of a method. Furthermore, it is often difficult to trace the series of amendments of a method over time when only the original description is found. A database of methods including Standard Operation Protocols (SOP) such as ECVAM's Scientific Information Service (SIS) is very helpful to enable the successful transfer of methods. Such databases should involve the laboratory that developed the method to ensure completeness and permanent updating. Bottrill (2002) gives an overview of available databases on the homepage of FRAME and Grune et al. (2001) listed search strategies for 3R-methods on the internet at the Linz 2001 meeting on alternatives.

\subsubsection{Awareness}

The individual scientist must be made aware of the opportunities and advantages of in vitro techniques. Therefore, the body of methods and concepts must become an integral part of any education in the life sciences. It is timely to implement the subject formally in education programmes, install chairs on alternative methods and establish courses and pro- 
grammes (including internet-based offers). The educated mind is the best messenger to disseminate alternatives. Following academic education, students take over responsibilities in academia, industry and authorities, leading to an amplification of the taught ideas.

\subsection{Advantages and disadvantages of in vitro compared to in vivo models}

\subsubsection{Advantages of in vivo models}

- Homeostasis - the living organism maintains the composition of body fluids with efficiency hardly achievable in vitro - Completeness - the in vivo model comprises all aspects of adsorption, distribution, metabolism and excretion of agents and toxins

- Inclusion of systemic responses - contributions of other organs and especially of the immune system are difficult to model in vitro

- Low-tech - most animal experiments for regulatory purposes and many experimental set-ups in basic research do not require very expensive equipment. But due to the creation of transgenic and cloned animals, the tendency is moving towards a technically more complicated phase.

\subsubsection{Disadvantages of in vivo models}

- Ethics - consumption and suffering of animals require justification

- Species differences - considerable differences are found between species or even strains of species, especially in comparison to humans

- Costs - both the production and the keeping of animals under quality-controlled conditions is laborious and expensive. The demanding care and low throughput make animal experiments costly.

- Statistically underpowered - as discussed above.

\subsubsection{Advantages of in vitro models}

- Costs - in vitro models usually require investment, e.g. to install cell culture laboratories, but are in general less expensive than a comparable animal experiment

- Throughput - since in vitro systems can be automated (e.g. pipetting robots) they allow standardised performance, e.g. required for high-throughput pharmaceutical screening

- Replicates - the number of replicate experiments is less limited than in vivo

- Simplicity - compared to the complex- ity of a whole organism, cell models comprising one or few cell types are much simpler, easing interpretation and deduction of mechanisms

- Accessibility - in most in vitro models the experiment can be stopped instantly or monitored continuously by bringing measurement devices into close contact

- Reduction of variance - a rank order of decreasing variation leads from a natural population of animals to standardised animals (age, weight, gender) to out-bred strains to in-bred strains to primary cells to cell strains to monoclonal cell lines; each step on this row represents a reduction in variance which in turn makes significant differences in experiments more likely (i.e. lower numbers of replicates required)

- Use of human materials - a major advantage with regard to extrapolation to the human situation. However, dedifferentiation and in vitro artefacts have always to be excluded.

\subsubsection{Disadvantages of in vitro models}

- Artefacts - the multitude of variables brought into a given in vitro system (e.g. ingredients of media, devices, intervals for culture steps) influence the status of the cells, their responses and thus experimental results

Tab. 5: Some alternative websites and databases concerning basic research (not exhaustive)

\begin{tabular}{|c|c|}
\hline ALTEX & (Alternatives to Animal Experimentation, $\mathrm{CH}$ ) - www.altex.ch \\
\hline Altweb & (Alternatives to Animal Testing on the Web, USA) - http://altweb.jhsph.edu \\
\hline AVAR & (Association of Veterinarians for Animal Rights, USA) - www.avar.org \\
\hline AWIC & (Animal Welfare Information Center, USA) - http://netvet.wustl.edu/awic.htm \\
\hline CAAT & (Center for Alternatives to Animal Testing, USA) - http://caat.jhsph.edu/ \\
\hline ECVAM & (ECVAM Scientific Information Service, EU) - http://ecvam-sis.jrc.it/ \\
\hline FBL3R & (Foundation Biographics Laboratory 3R, CH) - http://www.biograf.ch/ \\
\hline FFVFF & (Foundation for Animal Free Research, CH) - http://www.ffvff.ch \\
\hline FR3R & (Foundation Research 3R, CH) - http://www.forschung3r.ch/ \\
\hline FRAME & (Fund for the Replacement of Animals in Medical Experiments, UK) - http://www.frame.org.uk/index.htm \\
\hline HSUS & (Humane Society of the United States, USA) - http://www.hsus.org \\
\hline ICCVAM & (Interagency Co-ordinating Committee for the Validation of Alternative Methods, USA) - http://iccvam.niehs.nih.gov/ \\
\hline NCA & $\begin{array}{l}\text { (The Netherlands Center Alternatives to Animal Use) - http://www.nca-nl.org/ } \\
\text { Norwegian Reference Center }\end{array}$ \\
\hline NORINA & (Norwegian Inventory of Alternatives) - http://oslovet.veths.no/norina/ \\
\hline SFRWAE & (Swedish Fund for Research without Animal Experiments) - http://www.algonet.se/ \\
\hline SET & (Foundation for the Replacement of Animal Experimentation, D) - http://www.tierversuche-ersatz.de/ \\
\hline UCCAA & (University of California Center for Animal Alternatives, USA) - http://www.vetmed.ucdavis.edu/Animal_Alternatives/main.htm \\
\hline ZEBET & $\begin{array}{l}\text { (Center for Documentation and Evaluation of Alternative Methods to Animal Experiments, D) - } \\
\text { http://www.bgvv.de/cms/detail.php?template=internet_de_index_js }\end{array}$ \\
\hline ZET & (Center for the Replacement of Animal Experimentation, A) - http://www.zet.or.at/ \\
\hline
\end{tabular}


Sub-selection - even primary cells represent a sub-selection of the natural population, since more robust cells will be favoured; the situation becomes more extreme in case of strains or cell lines which are usually oligo- or monoclonal and hardly reflect the natural variety; the reduction in variance (see above) endangers the relevance of the model

- Dedifferentiation - cells taken out of their natural environment with various feedback signals and metabolic demands tend to loose differentiation, i.e. the specific set of genes expressed to fulfil organ function are no longer expressed; this loss of function is further promoted by the non-homeostatic culture conditions, e.g. the change of medium which suddenly takes away the conditioned environment, removes all waste products and replenishes nutrients. Such sudden changes favour flexible responses and thus less differentiated pluripotent cells

- Long-term exposure and maintenance - so far no routine solutions for longterm experiments, e.g. exposure to low level toxins, have been devised; perfusion culture systems are emerging but still lack standardisation and validation

- Cell density - cell cultures are considered dense at about 1-2 million cells per $\mathrm{ml}$ (in a typical suspension culture); in tissue, at least 100fold higher densities are achieved and cell cultures thus hardly reflect the cell-to-cell interaction of the organism

- Oxygen supply - the lack of access to oxygen represents a major limitation of cell culture: the oxygen dissolved in fresh culture medium is consumed during the first few hours of culture and diffusion from air to the cells is limited, resulting in anaerobic metabolism and accumulation of lactate, shifting the $\mathrm{pH}$.

This list is far from complete. It shows that although much has been achieved to approximate organ-like cell culture, many technological problems have not yet been solved. This situation calls for basic research in cell and tissue culture to improve the relevance of in vitro models. The closer an in vivo-like behaviour is approximated, the more likely the in vivo situation is reflected in relevant test results.

\section{Examples of published alternative methods in basic research}

The following methods are presented to show examples of the variety of alternatives published in the field of basic research. The examples chosen originate predominantly from Switzerland, Austria and Germany and the manuscripts have been published in ALTEX.

However, despite successful publication of alternatives, the number of animals used in basic research is still increasing. One reason appears to be the enormous specialisation in basic research, employing very individual setups and experimental models. Very often the alternative method is only used in the project it was developed for, but not in other groups working in similar fields.

Table 6 gives an overview of some published methods for alternatives in basic research and an estimation of their chance to be applied world-wide. In contrast to regulatory tests, which have to be replaced as exactly as possible to minimise exposing consumers or workers to risk, in vitro techniques which only partially mirror the in vivo situation also have merits in basic research. While a clear-cut prediction model is required for safety tests, i.e. how to predict the outcome of a clearly defined animal experiment by the in vitro data, only the relevance of data counts in basic research. Often the respective animal experiment cannot even be precisely defined, or a whole class of in vivo experiments or different species might be used to study similar phenomena. Most often, the modern in vitro techniques offer opportunities far beyond what is

Tab. 6: Methods in basic research described in this article and perspectives in the sense of the 3R

\begin{tabular}{|c|c|c|c|}
\hline Methods & description & authors & state of development \\
\hline \multicolumn{4}{|l|}{ In vivo } \\
\hline Incubated chicken egg & Inoculation of tumour cells on the CAM & Kunzi-Rapp (1997) & (2) \\
\hline Incubated chicken egg & Production of monoclonal antibodies & Hlinak et al. (1997) & $(0)$ \\
\hline Transgenic animal models & $\begin{array}{l}\text { Genetically modified animals (knock out, } \\
\text { knock in, humanised animals) }\end{array}$ & $\begin{array}{l}\text { first described by } \\
\text { Palmiter et al. (1982) }\end{array}$ & (3) \\
\hline $\begin{array}{l}\text { Better anaesthetics } \\
\text { and analgesics }\end{array}$ & $\begin{array}{l}\text { Better pain management reduces stress } \\
\text { experienced by the animals }\end{array}$ & Flecknell $(1994,1996)$ & (3) (9) \\
\hline Humane endpoints & Typical refinement, death is to avoid as an endpoint & Hendriksen and Morton (1999) & (3) (9) \\
\hline $\begin{array}{l}\text { Computertomographic } \\
\text { methods }\end{array}$ & Non-invasive observation of brain activity & e.g.: Lee et al. (1998) & (3) \\
\hline $\begin{array}{l}\text { Enrichment in } \\
\text { animal housing }\end{array}$ & $\begin{array}{l}\text { Enrichment of the monotonous cage, } \\
\text { satisfaction of elementary behavioral needs }\end{array}$ & Weerd et al. (2002) & (3) (6) \\
\hline
\end{tabular}

\section{Animal tissue}

Brain slice technique

Rabbit aorta organ culture model

Isolated porcine organs from the abattoir
30 preparations out of one rat brain

10 aorta preparations can be made from one animal

Normothermic hemoperfused

porcine leg

Normothermic hemoperfused porcine heart

$\begin{array}{ll}\text { Olpe and Haas (1985) } & \text { (3) (4) } \\ \text { Finking et al. (2000) } & \text { (3) (5) }\end{array}$

Nogueira et al. (1999)

(3)

Ast et al. (2001)

(3) 
Methods

description

authors

state of development

Human tissue

Human vascular cells

Transfilter Co-culture system is used for research on atherosclerosis and restenosis

Siegel-Axel (1999)

(3) (4)

Human cell-based cell function analyser Cell-vessel wall interactions (adhesion, emigration)

Human umbilical

Detecting anti-endomysium antibodies

Reininger (2000)

cord sections

Izzi (1998)

(3) (5)

\section{Cell culture models}

Hepatocyte bioreactors

Comparison of the efficiency of four different bioreactors

Nussler et al. (2001)

(3)

Co-cultivation of hepatocytes with parenchymal cells

Cancer research

\section{Overview}

Automatic analysis system to detect the potential of cancer chemotherapy

Rodent fibroblasts and embryo cells are used to determine the carcinogenic potential of inorganic chemicals

Stem cell methods

Embryonic stem cells (ES) are used to determine embryotoxic endpoints and neurotoxicity

Zeilinger et al. (2000)

Tritthart (1996)

Gutsche and Stelzner (1997)

Combes et al. (1999)

Overview by Wobus

given in Linz 2001

(s. ALTEX 3/2001)

(Seiler et al. 2001)

(Arnhold et al. 1998)

Genetically modified cells Insertion of "human" attributes into immortalised cells Artificial membranes

Monolayers or sophisticated co-culture models allowthe simulation of transport mechanisms across biological barriers

Doehmer (2001)

Overview by

Gindorf et al. (2001)

\section{Antibody production}

In vitro production of monoclonal antibodies

Recombinant antibodies

Use of chicken IgY antibodies (together with altern. adj. and appropriate housing)

Use of alternative adjuvants and moderate immunising methods
Different cell culture methods are available to produce very different amounts of antibodies

Immunoglobulin chains are cloned and recombined in a bacteriophage vector

Specific antibodies can be obtained from the egg yolk of immunised chickens

Replacement of the "hard" Freunds adjuvans by "soft" alternative adjuvants is mostly sufficient

\section{Overview by}

Marx et al. (1997)

Overview by

Stadler et al. (2002)

Overview in

ALTEX Suppl. (1996)

(3) (9)

(3) (5)

(3) (6)

Overview in Leenars

et al. (1999)

(3) (5)
Falcone et al. (1995)

(3) (6)

In vitro cultivation of arthropods or other parasites is often possible
Kuhnert (1996)

Matthes and Hiepe (1996)

Kuhnert et al. (1998)

\section{In silico alternatives}

CADD - computer assisted drug design

The Ehrlich's key and key-hole principle has consequences for QSAR methods (quantitative structure action relationship)

(0) method has shown no further consequences;

(1) method is restricted to the developing laboratory;

(2) some other laboratories have adopted the method;

(3) method is of great international interest;

(4-8) method has already reached different steps of evaluation/validation;

(9) method is evaluated/validated;

(10) no more animals are in use for this purpose

Vedani (1994)

Vedani and Dobler (2001)

(3) (4) 
feasible in vivo. Considering them as a mere replacement is underestimating their potential. This potential is the major driving force for change - a scientist will be reluctant to change his method if this does not entail further advantages. Thus, modern in vitro techniques can be more than alternatives to animal experiments, but they profit considerably from establishing relevance and reproducibility similar to a validation procedure. It might be necessary to coin a new terminology, e.g. speaking of valid in vitro tests instead of validated alternatives.

\subsection{In vivo alternatives}

\subsubsection{The incubated chicken egg as an alternative method}

The incubated chicken egg can be used to study ocular and mucosal toxicity, angiogenesis, aspects of tumour biology or the effects of heavy metals, functional parameters of the cardiovascular system and effects of drugs on this system. The embryo is insensitive in the early stages of incubation; sensitivity develops stepwise only starting around day 7, thus this model is an alternative method in accordance with the 3Rs if employed within the first week of incubation (Rosenbruch, 1994, 1997).

The model has been employed to characterise tumour growth (Kunzi-Rapp, 1997), replacing the use of nude mice. The extra-embryonal vascular system of the chorioallantois membrane (CAM) offers an excellent substrate. Vascularised organotypical tissues develop from cell suspensions applied to the membrane within a few days. Solid tissue sections, e.g. human biopsy material, are attached to and supplied by the vascular system of the chicken embryo within 48 to 72 hours. Results from this model correlate well with cell culture observations as well as with in vivo animal experiments. Shoin et al. (1991) used the HET CAM as chemosensitivity test for malignant glioma tumors. To predict the efficacy of anticancer drugs they graftet human tumors on the chorioallantois membrane of chick embryos (see Fig. 5). In $78 \%$ instances the assay response corresponded to a clinical partial response, true negative resonse occurred in $100 \%$ of all cases.

The CAM method is accepted worldwide for investigations on angiogenesis, however its acceptance and use for the other applications appears only slowly to be growing. It can be used as an intermediate assay between cell culture and animal experiment, e.g. for dose-finding or tighter screening of selected substances, reducing the number of animals required for subsequent experiments.

Hlinak et al. (1994) employed the incubated chicken egg in order to produce monoclonal antibodies to avoid the ascites mouse system. This approach,

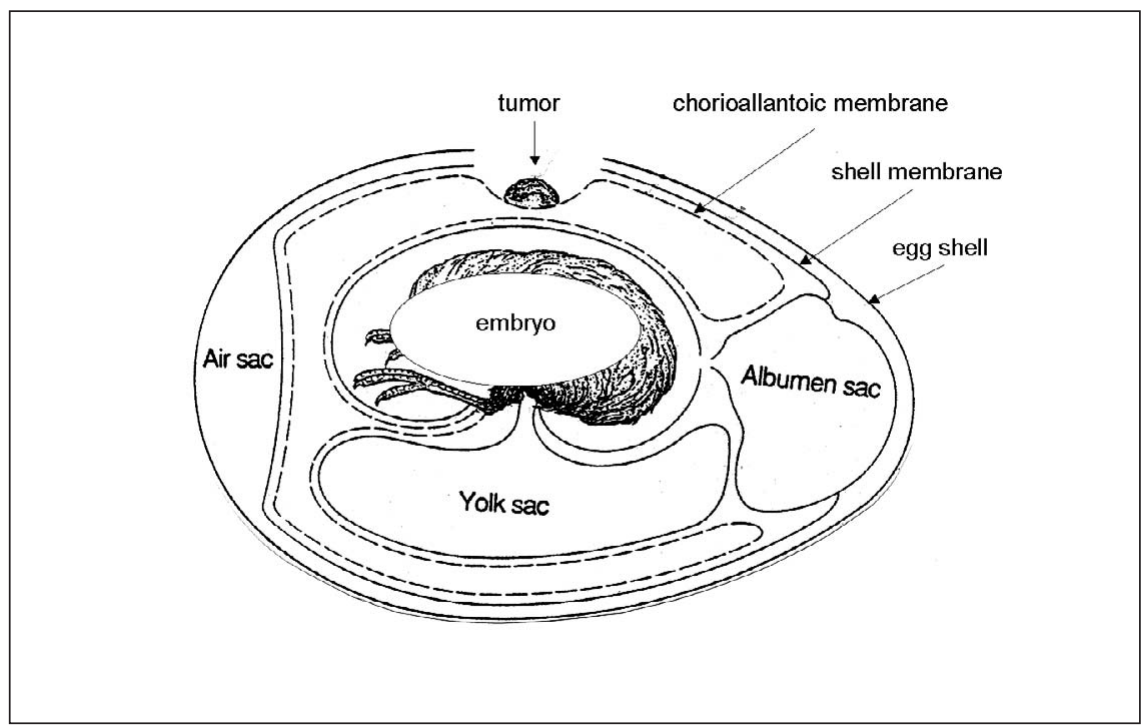

Fig. 5: Schematic drawing a chemosensitivity test system using the chorioallantois membrane (HET CAM) of fertilised chicken eggs (Shoin et al., 1991)

though pragmatic at the time, was quickly eclipsed by in vitro methods (see below).

\subsubsection{Transgenic animal models}

Delpire and Balls (1998) report the results of an ECVAM workshop about the use of transgenic animals in the European Union. It was obvious that possible advantages as some aspects of refinement are threatened by transgenic procedures which may promote greater animal use, more-varied applications, and the greater likelihood of animal suffering. The generation of transgenic mouse models is the main reason for the current increase in the number of experimental animals. However, in certain cases, transgenic mice are considered by some to be promising tools for refinement. The use of transgenic mice instead of primates could involve less stress to the animals; transgenic animals with increased susceptibility could shorten toxicity studies. There are some positive examples of transgenic animals allowing the use of fewer animals in total to answer a specific research question (Gruber, 1998). On the other hand, large numbers of animals are required to "produce" transgenic strains. Also, it is not clear whether these animals suffer more from diseases than their wild-type counterparts. Thon et al. (2002) showed that $36 \%$ of the transgenic strains which were reported experienced discomfort $(21 \%$ minor and $15 \%$ severe discomfort). In addition $30 \%$ of the strains were reported to have increases in mortality, disease incidence and susceptibility to disease. The most frequently mentioned conditions being increased mortality, decreased fertility and diabetes.

However, it should be noted that most of these animals are required for breeding of the transgenic animals and not for animal experiments. The often disabling effects of gene knock-outs and knock-ins must not be neglected, but the suffering caused is considerably less than in most other animal experiments. Nevertheless, a discussion has to be initiated urgently on how animal numbers can be made to decline again and, as a minimum immediate first step, how suffering of these animals can be minimised. Especially, the precision of the microinjection tech- 
nique requires drastic improvement to reduce the animal numbers.

A comprehensive form for the standardised documentation of transgenic rodents (genotype, phenotype, welfare assessment, recommendations for refinement) was developed by Mertens and Rülicke, 2000. They argue that during the "creation" of transgenic mouse strains it is impossible to predict their phenotype with certainty, particularly with respect to welfare. The form is subdivided into basic and detailed information and can be updated continuously in the form of a computerised database, incorporating growing knowledge and experience with the strain. The complete form can be downloaded from www. altex.ch/news_e.htm\#topics.

With regard to the $3 \mathrm{Rs}$, activities are underway to define criteria for the discontinuation of experiments (refinement) and to target gene insertions more efficiently (reduction) in order to limit increases in these animal numbers.

Anyway, it must be evaluated on an individual basis to what extent transgenic animals can contribute to the $3 \mathrm{Rs}$.

\subsubsection{Refinement during procedures, e.g. anaesthetics and analgesics}

Better anaesthetics and analgesics are the classical refinement methods. Continuous improvement of these procedures leads to a significant reduction of stress in the animal experiment (Flecknell, 1994, 1996). Required by law in almost all countries practical application is often still inadequate. Authorities and animal welfare officers are responsible to demand and enforce the newest insights and progress in their institutes. Sadly, there are often great discrepancies between state of the art and daily practice. Overview in Flecknell and Waterman-Pearson (2000).

\subsubsection{Refinement during procedures, e.g. humane endpoints}

Hendriksen and Morton (1999) edited the "Proceedings of the international conference on humane endpoints in animal experiments for biomedical research", which contains much information on refinement measures in toxicology and points out how changes

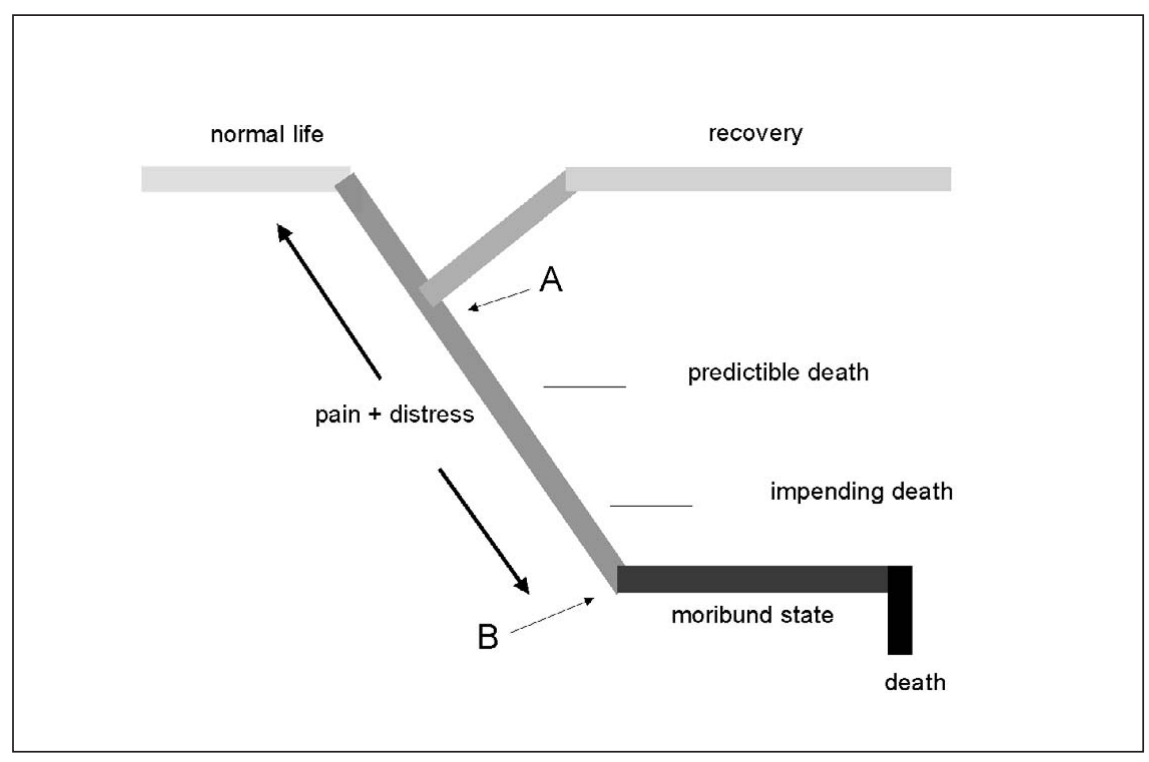

Fig. 6: Humane endpoints. The point to end an experiment has to be choosen as near as possible to point (A) and as far as possible to point (B)

can be made towards more humane endpoints in basic research. The Swiss "Ethical principles and guidelines" of the Academies of Natural and Medical Science (SAMW and SANM, 1996) state that a procedure, which leads to severe suffering, cannot be weighed up by gain of knowledge and should therefore be abstained from. Similarly, Morton (1999) wrote, "... when the level of suffering is so high that it is simply wrong to cause that degree of harm to an animal...". An interesting phrase was coined by Balls (1999). He does not speak of "humane endpoints" but prefers the wording "less in-humane animal procedures".

The estimation of pain and suffering still plays a central role in the humane endpoints. Therefore, it is important to know how experienced authors see the possibility of objective evaluation, e.g. Wolfgang Scharmann (1999), "Physiological and ethological aspects of the assessment of pain, distress and suffering"; Jones, Oates and Trussell (1999), "An applied approach to the assessment of severity" and Lloyd and Wolfensohn (1999), "Practical use of distress scoring systems in the application of humane endpoints". Wallace (1999) considers humane endpoints in cancer research.

The animal experiment or ethics commissions or the animal care committees play a pivotal role in the definition of cri- teria for the cessation of the experiment, which should be a central aspect of all approval procedures (Mench, 1999).

To clarify the situation of defining humane endpoints, Figure 6 shows the chronological events which should trigger the premature termination of an experiment. Clear termination criteria already defined in the approval of an animal experiment, regular health checks and the continuous presence of a competent and decisive person in charge of the experiment are important to ensure a timely and animal protection relevant termination of the procedure.

\subsubsection{Refinement during procedures, e.g. magnetic resonance imaging}

A major challenge for basic research will be the development of methods to replace implanted sensors in brains of animals, especially primates, by imaging methodologies. While in the EU a ban of experiments on primates is discussed (Balls, 1995), and some philosophers do not accept invasive procedures on primates at all (Flury, 1999) some research institutions (for example the University of Bremen) are expanding their respective primate facilities in order to accommodate neurophysiologists. The problem of replacing the recording of single cell potentials from defined brain areas by 
imaging techniques is still the insufficient resolution of current methods. Therefore, novel approaches to gain neurophysiological data by non-invasive methods require our specific attention and support.

Lee et al. (1998) studied the changes in the intrinsic magnetic resonance (MR) relaxation parameters of the marmoset head, imaged before and after death. Knowing the absolute values of the MR parameters made it possible to choose an imaging protocol for optimal structural differentiation. The changes between the ante-mortem and post-mortem MR parameters provide an insight into the changing biophysical microenvironment of the post-mortem brain, and allow some of the changes that occur in pathological conditions to be predicted. Diffusion-weighted MR imaging (MRI) was used to map quantitative apparent diffusion coefficient values, and to investigate diffusional anisotropy along the fibre tracts in pre-mortem and post-mortem brain tissue. A three-dimensional set of data of the entire marmoset brain demonstrates the ability of three-dimensional MRI to differentiate internal brain structures. MRI is a non-invasive technique that, in principle, permits the same animal to be re-imaged serially and has the potential to probe in vivo brain structural and biophysical changes over an extended period of time. Serial imaging, in which each animal acts as its own control, reduces the number of animals required to detect a significant change by minimising inter-subject variance. MRI therefore provides important scientific and ethical benefits.

As important as the introduction of these methods is, it cannot substitute for single cell measurements required by some scientists. A further disadvantage is the expense of this method. However, if one takes the German Animal Protection Law seriously, the replacement of an animal experiment may not be put off because the alternative is more expensive, requires more time or more personnel. (§ 9,2, Ziff. 3, TierSchG, 25.5.1998). However, it has many advantages over the invasive method too. Functional Magnetic Resonance Imaging (fMRI) like it is described by Motzkus et al. (2004) even can be used for objective but stressfree pain research.

\subsubsection{Enrichment in animal keeping, considering the needs of behavioural biology}

Breeding, transport and keeping of animals have also become targets for measures of refinement. The EU directive 86/609/EEC sets minimum standards for experimental animals in the member states. However, already at implementation in 1986, the directive did not reflect the state of the art standards of behavioural science but represented a harmonisation at the lowest level. Discus-

Tab. 7: Comparison of the answers of some ethologists and laboratory animal scientists to six specific questions about better housing of rodents

\begin{tabular}{|c|c|c|c|c|c|c|}
\hline $\begin{array}{l}\text { answering } \\
\text { scientists }\end{array}$ & $\begin{array}{l}\text { Question 1: } \\
\text { Do there exist } \\
\text { definitively } \\
\text { identified etho- } \\
\text { pathies? }\end{array}$ & $\begin{array}{l}\text { Q2: Is it allowed } \\
\text { to compare } \\
\text { behaviour of } \\
\text { laboratory } \\
\text { animals with } \\
\text { the wildtype? }\end{array}$ & $\begin{array}{l}\text { Q3: Is there } \\
\text { evidence } \\
\text { for impaired } \\
\text { housing } \\
\text { conditions? }\end{array}$ & $\begin{array}{l}\text { Q4: Is there } \\
\text { evidence for } \\
\text { bad scientific } \\
\text { results caused } \\
\text { by wrong } \\
\text { animal housing? }\end{array}$ & $\begin{array}{l}\text { Q5: What are } \\
\text { the reasons } \\
\text { not to alter } \\
\text { housing } \\
\text { conditions? }\end{array}$ & $\begin{array}{l}\text { Q6: Do there } \\
\text { exist debatable } \\
\text { recommendations } \\
\text { for better housing? }\end{array}$ \\
\hline A & yes & makes no sense & yes & yes & no reasons & yes \\
\hline $\mathrm{B}$ & difficult & yes, but carefully & $\begin{array}{l}\text { rats and mice } \\
\text { have a good } \\
\text { adaptation }\end{array}$ & no & $\begin{array}{l}\text { adaptation over } \\
100 \text { generations, } \\
\text { hygiene }\end{array}$ & yes \\
\hline $\mathrm{C}$ & not yet evident & $\begin{array}{l}\text { shall not be } \\
\text { usedas recom- } \\
\text { mendation for } \\
\text { laboratory animals }\end{array}$ & $\begin{array}{l}\text { not yet evident, } \\
\text { maybe Hurst }\end{array}$ & & $\begin{array}{l}\text { enrichment is only } \\
\text { recommendable } \\
\text { if real improvement } \\
\text { is to await }\end{array}$ & it has to be discussed \\
\hline $\mathrm{D}$ & no & no & $\begin{array}{l}\text { no sure } \\
\text { evidence }\end{array}$ & & $\begin{array}{l}\text { validity, } \\
\text { disposability, } \\
\text { practicability, } \\
\text { lower costs, } \\
\text { missing } \\
\text { regulations }\end{array}$ & no \\
\hline$E$ & no & no & yes & & & yes \\
\hline $\mathrm{F}$ & some hints & yes & yes & $\begin{array}{l}\text { mice may be } \\
\text { more active, } \\
\text { results therefore } \\
\text { more reliable }\end{array}$ & $\begin{array}{l}\text { lower costs, } \\
\text { practicability, } \\
\text { but problematic } \\
\text { standardisation }\end{array}$ & yes \\
\hline $\mathrm{G}$ & no (rodents) & $\begin{array}{l}\text { it is the only } \\
\text { possibility }\end{array}$ & no & $\begin{array}{l}\text { yes, in neuro- } \\
\text { physiology }\end{array}$ & $\begin{array}{l}\text { hygiene, } \\
\text { oeconomics }\end{array}$ & yes \\
\hline $\mathrm{H}$ & $\begin{array}{l}\text { not evident on a } \\
\text { scientific base }\end{array}$ & maybe in quality & difficult & & $\begin{array}{l}\text { international } \\
\text { regulations }\end{array}$ & yes \\
\hline I & yes & yes & yes & yes & & yes \\
\hline $\mathrm{K}$ & sometimes & $\begin{array}{l}\text { has to be } \\
\text { considered but } \\
\text { not for recom- } \\
\text { mendations }\end{array}$ & principally yes & $\begin{array}{l}\text { no, but mistakes } \\
\text { possible }\end{array}$ & $\begin{array}{l}\text { all over approved } \\
\text { but need for } \\
\text { better evaluation }\end{array}$ & no \\
\hline
\end{tabular}


sions on updating the guideline are ongoing, but this is made difficult by widely differing opinions of scientists (Tab. 7).

This controversy prompted a workshop initiated by the Swiss Foundation 3R and the German Foundation "set" which reached the following results (s. Tab. 8).

Animals can perform more natural, species-specific types of behaviour in "enriched" environments. Enrichment provides the animal with a more stimulating and responsive environment, such as cage mates, nesting material, hiding places. It is postulated that animals from enriched environments cope better with novel situations, and thus might offer more relevant experimental results with less biological variation (Van der Weerd et al., 2002), despite some studies claiming the contrary though based on less relevant endpoints (Gärtner, 1999). Hopefully, the EU directive will be updated as promised, as this might also affect animal keeping outside of Europe.

It appears to be feasible to achieve a major advance in appropriate conditions for animals by refining standards for housing laboratory animals. In Figure 7 it is shown that previous quantum jumps in refining laboratory animal husbandry to the currently existing regulatory guidelines largely have been based upon laboratory animal science, whereas consider- ation of ethological knowledge recently has raised the awareness for the need for further improvements (Gruber, 1996).

\subsection{Isolated organs as models in basic research}

\subsubsection{Animal tissue and organs in research}

The use of isolated organs in experimental procedures is one of the most effective methods to reduce the number of animals and the severity of stress. Animal organs can be obtained from laboratory animals or from slaughterhouses.

One of the first ex vivo models described in ALTEX was the brain slice technique (Olpe and Haas, 1985). Up to 30 preparations can be made from the brain of one rat. These can still be used for experiments hours later. Finking et al. (2000) established an organ culture

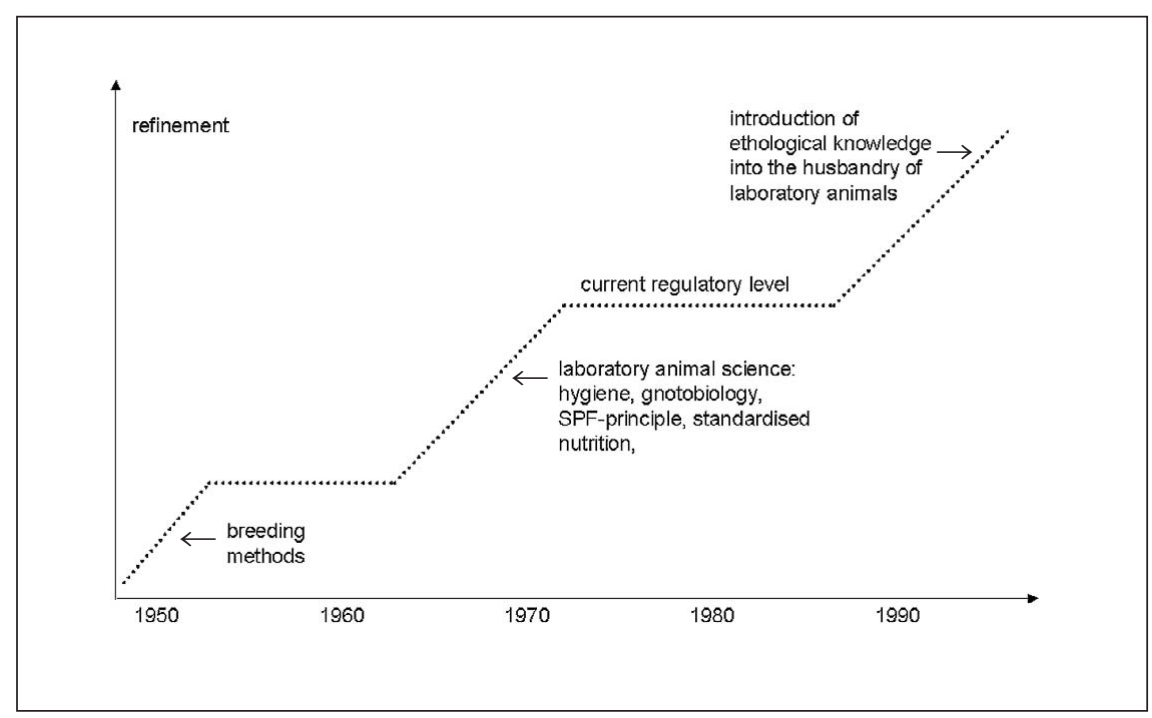

Fig. 7: "Quantum Jumps" in the refinement of laboratory husbandry by breeding methods, laboratory animal science und ethology (Gruber, 1996)

Tab. 8: Methods and results of a workshop about better housing of laboratory animals

organised by the Center for Laboratory Animal Husbandry and Welfare (KLab) at the Institute of Animal Sciences, ETH Zürich. Participants were scientists, representatives of the two funding bodies, and legal authorities from the Swiss Federal Veterinary Office. Participants agreed on the following priorities for future research:

\begin{tabular}{l}
\hline Behavioural ecology of laboratory animal species, mechanisms underlying behaviour, cognition, interindividual differences, non- \\
invasive indicators of impaired welfare, and husbandry effects on experimental results. \\
\hline Multidisciplinary and interdisciplinary approaches should be pursued to use present knowledge most effectively. \\
\hline However, it was also agreed that a framework was needed to facilitate research into how animals' behaviour in their natural habitat \\
met by the environment. \\
ms a result of a follow-up meeting with leading ethologists in 1998 (again organised and chaired by the KLab), a research strategy is \\
currently being developed with the goal of identifying reliable behavioural indicators of impaired welfare. \\
\hline Conclusions and relevance for $3 R$ \\
\hline The relationships between suffering and pathology need to be understood from an evolutionary point of view. \\
pathological changes), if, and only if, such experiences are instrumental in avoiding fitness costs by means of behavioural changes. \\
\hline This view implies on the one hand that conditions leading to pathological changes do not necessarily induce suffering. \\
\hline On the other hand, suffering may occur under conditions that do not induce pathological changes. \\
changes does not guarantee good welfare. \\
\hline In consequence, behavioural changes associated with threats to fitness (e.g. avoidance behaviour) and behavioural signs that the \\
animals' attempts to adjust their behaviour have been stymied (e.g. stereotypies) represent the most direct indicators of suffering \\
induced by inappropriate husbandry conditions.
\end{tabular}

This workshop was sponsered by the German Foundation "set" and the Swiss Foundation Research 3R 
model (rabbit aorta) to investigate postinjury estrogen effects in the vessel wall. As 10 aortic segments could be taken from one aortic vessel, the number of animals necessary for an in vivo experiment could be reduced 10-fold and the stress was reduced to zero. The isolated normothermic hemoperfused porcine leg, a model to investigate transdermal resorption and vasoactive substances, was first described by Nogueira et al. (1999). Legs and blood can both be obtained from a slaughterhouse. From the same group (Ast et al., 2001) came the normothermic perfused porcine heart, developed for the experimental determination of QT-prolongation in ECG, which can occur as a side effect of different drugs. This could replace in vivo experiments on 1500 dogs per year worldwide in addition to many more rodents (Bruno Christ, personal communication). Pittermann et al. (2000) published "Proceedings of a workshop on isolated perfused organs", which was held 1998 in Hamburg during the 36th Scientific Meeting of GV-SOLAS. It was apparently that with abattoir material the use of laboratory animals can be reduced and that kinetic parameters of drugs could be measured much more precisely.

Sadri (2002) wrote, "Isolated organ perfusion technology offers many advantages over other experimental models, such as using live laboratory animals, conducting human clinical trials or testing cell cultures. For example, if a researcher is studying the beneficial or toxic effect of a particular drug, then perfusing and testing an isolated viable organ is far more likely to generate unambiguous results than using more traditional research methods. Similarly, dosage studies conducted on a perfused organ are far more likely to produce reliable data."

\subsubsection{Human tissue and organs in research}

Human tissue can be used in basic research for the prediction of efficacy (e.g. receptor binding assays and enzyme inhibition), but also for the prediction of safety as well as for metabolism and pharmacokinetic studies (e.g. with human microsomes). However, human tissue should only be handled by ade- quately protected and trained personnel. In some European countries (UK, Netherlands, Germany) the patient must agree explicitly to the use of the tissue for scientific purposes, in other countries the patient must explicitly refuse (France, Belgium, Poland).

In an ECVAM workshop (Anderson et al., 2001) the creation of an ENRTB (European Network of Research Tissue Banks) was suggested, which should ensure high quality standards to ensure reproducibility of results with respect to viability and characterisation. Individual RTB's should promote the validation of alternative methods involving in vitro human tissue models.

Three examples of alternative methods are presented here.

Siegel-Axel et al. reported in 1999 on an in vitro method of transfilter co-cultures of human vascular cells with blood cells, imitating the morphology of the arterial vessel wall to investigate antiproliferative and anti-migratory therapeutic strategies for atherogenesis and restenosis. The transfer of the results to the human situation on the basis of these in vitro studies seems to be greater than with most animal models. Other institutes have adopted this method successfully.

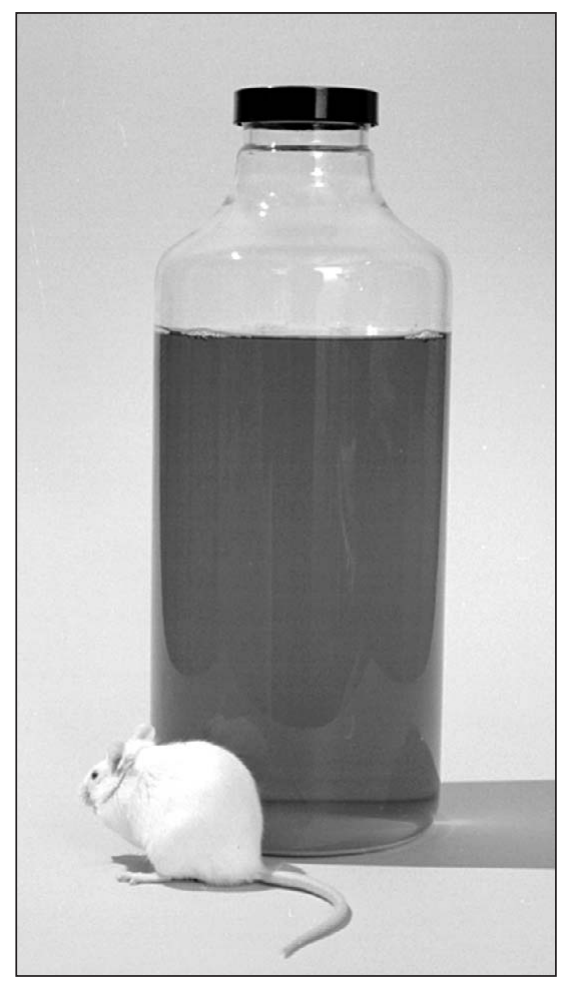

Reininger (2000) described a human cell function analyser (CFA) - a physiological in vitro vascular model with which cell-vessel wall interactions (adhesion, emigration) and cell-cell cohesion (aggregation) can be assessed. The three components of Virchow's triad are present in a highly standardised and variable form. Specimen fixation and histomorphological analysis after the experiment is possible. The efficacy of the method for testing of platelet function has been verified by numerous clinical studies. The wide variability of test parameters suggests CFA to be suitable for in vitro analysis of other cell - vessel wall mediated processes, such as inflammation, wound healing and tumour metastasis. However, the CFA provides no direct in vitro alternative to animal experiments and several efforts to establish the method at other institutes were unsuccessful.

Use of human umbilical cord sections to detect anti-endomysium antibodies for celiac disease screening was described by Izzi (1998). The original assay was limited by the use of endangered species tissue (monkey distal oesophagus) as well as by the high cost of commercial kits. The new test is based on immuno-fluorescence and an ELISA. However, despite the good results of the new test, both kits are still available, as the killing of animals for experimental use is not considered an animal experiment in many countries and so the established alternative method is not mandatory.

\subsection{Cell culture models}

Cell culture models as typical in vitro models represent the backbone of the alternative methods. Here especially the observation holds true that successes published in the relevant journals are not necessarily coupled with a real reduction of the number of experimental animals used in basic research. The reason is probably that technically we are still very much at the beginning of the culturing of cells and organs and very often a purely methodological advancement wakes the greatest hopes that this method may at some stage be able to replace animal experiments. It is very difficult to separate legitimate hope from mere assertions, 
which are made to ensure further financing of the project. Especially private foundations cannot be admonished enough, not to invest funds into such purely methodological projects without proper expert evaluation.

\subsubsection{The possibilities of hepatocyte cultures}

The suitability of hepatocyte culture models to study various aspects of drug metabolism was the topic of an ECVAM workshop (Blaauboer et al., 1994) and was reassessed by Nussler et al. (2001). Isolated rat hepatocytes have been increasingly used as a model to identify pharmacological and toxicological responses to drugs. However, they retain most of their functions only for a short period of time. Therefore, numerous models and techniques have been developed to study and improve the metabolic capacity of hepatocytes in vitro over an extended time period. Nussler et al. compared four different cell culture models and found that hepatocytes cultured within a collagen sandwich or in a 3D-membrane bioreactor retained drug metabolism over a longer time period. The development of these reactors has not yet advanced far enough to allow judgement of their $3 \mathrm{R}$ relevance. It has been shown that primary human liver may also be cultivated successfully, i.e. including maintenance of cell-specific functions, for a number of weeks (Wang et al., 2002). Methods to isolate, culture and differentiate liver stem cells for metabolism studies are being developed. The controlled proliferation and differentiation of human liver stem cells offers the possibility of sufficiently available and standardisable cultures and could eventually lead to studies contributing to the replacement of experimental animals in pharmacological metabolic studies. It is unknown how many animals are used worldwide for such studies. A similarly structured but significantly simplified model has now also been developed, which can be operated in standard incubators and is currently in the test phase.

A liver cell co-culture of hepatocytes and liver macrophages, the Kupffer cells, was established in order to model inflammatory processes (Hartung and



Wendel, 1993). Mediators released by Kupffer cells when stimulated by bacterial endotoxin induced hepatocyte cell death. The inflammatory cascade was further approximated by introducing neutrophilic granulocytes into the coculture (Sauer et al., 1996). The model was pre-validated with more than 100 pharmacological agents in collaboration with industrial partners. The overall correlation of in vitro results with the animal experiment were remarkable, both with regard to effects of substances and mechanisms. This project shows that even complex inflammatory reactions can be modelled in vitro.

\subsubsection{Cell culfures in cancer research}

An increasing variety of in vitro test systems is used in cancer research to detect mutagenic or carcinogenic factors, to improve diagnosis and therapy and to study cancer cell functions and metastasis (Tritthart, 1996). These in vitro techniques are not only superior to some animal experiments but often are the leading techniques. Improved 3D cell culture techniques, studies of membrane and organelle functions as well as molecular biology and genetic techniques are discussed in light of cancer research within strategic recommendations of the European Community (Europe Against Cancer). The multistep cascade of events during metastasis can be studied elegantly by in vitro techniques, making many painful animal experiments avoidable. Metabolically competent human cells are superior tools to uncover carcinogenic compounds and mutagenic factors.

Gutsche and Stelzner (1997) developed an automatic analysis system of suspended and adherent cells to detect the potential of cancer chemotherapy. Without the use of animal experiments, they were able to exclude dangerous substances and to find new pharmacologically active agents in cell cultures. They also provided information on the cytostatic activities of the agents. Their endpoints were the statistical distributions of the cell diameters of K-562 and L-929 cells using an electronic cell analyser (CASY1).

An ECVAM Workshop on "Cell Transformation Assays as Predictors of $\mathrm{Hu}$ man Carcinogenicity" was held in 1999 (Combes et al., 1999). A new, mechanistically based, in vitro strategy involving Balb/c 3T3 clone A31-1-1 mouse embryo fibroblasts was proposed at this workshop for the determination of the carcinogenic potential of inorganic chemicals, in order to establish priority of metal compounds to be tested and, whenever possible, to compare the in vitro results with the corresponding in vivo data. After harmonisation and standardization of the Balb/3T3 protocol, cells were exposed for 72 hours to a fixed dose $(100 \mu \mathrm{M})$ of 58 different metal compounds. The cytotoxicity induced by some metal compounds was found to be related to their chemical structure. The results of the systematic study on the metal-induced cytotoxic effects in the Balb/3T3 cell line could be arbitrarily classified into three groups according to the degree of cytotoxicity (Mazzotti et al., 2001). In the ECVAM workshop protocol, the potential of mouse fibroblasts and hamster embryo cells to be used to gauge the carcinogenic potential of metal compounds is described. The possibility of automation and the costs are discussed. But regrettable the $3 \mathrm{R}$ potential is not discussed or estimated. 
In 2004, an ECVAM expert meeting on the cell transformation assay was convened, which reviewed the status of development and recommended a pre-validation of both the Syrian hamster embryo cell (SHE) test and the Balb/c 3T3 assay, which is currently organised. In parallel, an OECD test guideline was elaborated, and therefore these novel assays promise to complement soon the in vitro battery for the assessment of carcinogenic health effects.

\subsubsection{Stem cell methods}

Great successes have already been achieved with animal stem cells, which can develop into all 3 germ layers. Anna M. Wobus received the Felix-Wankelanimal protection-research prize in 2001 for her contributions to this field. Human ES would offer an even greater research potential, but the ethics of their use are still under public debate.

The developmentally controlled expression of tissue-specific genes, proteins, ion channels and receptors during stem cell differentiation is the basis of several in vitro approaches:

1) "loss of function" assays with ES cells containing homozygous mutations of specific genes,

2) "gain of function" assays with ES cells overexpressing exogenous genes,

3) developmental analysis of teratogenic/embryotoxic compounds in vitro,

4) pharmacological assays and the establishment of model systems for pathological cell functions, and

5) the application of differentiation and growth factors for induction of selectively differentiated cells which, in the future, may be used as a source of tissue grafts.

Strübing et al. (1995) established an in vitro model system for the differentiation of synaptically coupled neurons from mouse embryonic stem cells (BLC-6), which is more efficient than using primary embryonic cells from animals or tumour cell lines. The electrophysiological characterisation of the BLC- 6 derived neurons shows that these cells carry the complex electrical properties of postmitotic neurons and are coupled by inhibitory and excitatory synapses. Arnhold et al. (1998) also used BLC-6 cells to study neurodifferentiation and neurotoxicity in vitro. Characterisation of neuronal cells revealed characteristic phenotypes equipped with neurotransmitters, e.g. glutamate. The effect of glutamate intoxication by the receptor agonist NMDA during early neuronal development could be studied by videomicroscopic time lapse in these cells.

Guan et al. (1999) also used embryonic stem cells to establish standardised protocols for cardiogenesis, myogenesis, neurogenesis and vascular smooth muscle cell differentiation.

The use of stem cells to establish molecular endpoints for the screening of embryotoxic chemicals was reported by Seiler et al. (2001), and Buesen et al. (2004). This test was developed at ZEBET (Berlin) and was successfully validated by an ECVAM study (Genschow et al., 2002, 2004). Contracting heart cells differentiated from ES were used to assess the embryotoxic potential of test compounds and compared to cytotoxic effects in differentiated 3R3 mouse fibroblast cells.

\subsubsection{Genetically modified cells}

The usual immortalised cell lines have much reduced metabolic capacities. Therefore, either primary cells are used, which require the killing of animals, or leftovers from operations in the clinics are employed, or another way is opened: Cellular gene technology, improvement of the metabolic capacity by human genes. The possibilities for combinations are endless. Doehmer received the FISEA Prize for his genetically modified V79 hamster cell cultures in 1990. The methodology is now used commercially (www.genpharmtox.de) and promises a further reduction of animal experiments in drug screening but also in basic research.

Since 1986, V79 Chinese hamster cells have been genetically engineered by introducing rat and human enzymes for studies on metabolism-dependent effects in toxicology and pharmacology under defined conditions (Doehmer and Jacob, 1994). The metabolic activation of potentially harmful chemicals is of interest in toxicology, because metabolites may have their own toxic potency. Anabolic and catabolic pathways of drugs are of interest in pharmacology, because metabolism has a decisive impact on the efficacy of drugs. As an example for the usefulness of V79 cells genetically engineered for metabolic competence, and their advantage over animal experimentation, metabolic activation of polycyclic aromatic hydrocarbons has been studied. Comparative studies using V79 cells expressing rat and human enzymes revealed striking differences in the metabolite profile, which made it evident that human beings are more at risk than rats, when exposed to polycyclic aromatic hydrocarbons. This suggests at the same time that results obtained from animal experimentation must be interpreted with caution if they form the basis of risk assessment. Doehmer (2001) suggests that all V79 constructs together form the V79 Cell Battery ${ }^{\circledR}$ which is capable of checking drug metabolism early in preclinical drug development with immediate relevance for the clinical testing of drugs. It would be impossible to obtain all these data from animal testing. In this way, the intrinsic problem of extrapolating data generated from animal testing to humans has been circumvented in this instance.

\subsubsection{Artificial membranes}

Fundamental biopharmaceutical parameters like transport across different biological barriers are essential to understand the availability of drugs in an early stage of development, as any pharmaceutically active agent must be able to overcome the body's natural protective mechanisms. Far-reaching replacement of all animal experiments with in vitro methods is to be expected, already because of the great efficiency of the new methods (high throughput screening).

Gindorf et al. (2001) carried out an excellent survey on the possibilities to simulate transport mechanisms across biological barriers in vitro. They compared cell culture models for the gastrointestinal barrier, the blood-brain barrier and the alveolar epithelium of the lung. In order to respond to the flood of new active ingredients currently being generated by combinatorial chemistry or molecular biological synthesis, selection procedures must be able to filter out drug candidates with the highest development 
potential rapidly and economically. A broad variety of biological barriers can be simulated in the laboratory by cell monolayer models. Apart from ethical aspects, the advantage of these in vitro test systems is that permeability studies can be performed at high throughput rates under controlled and reproducible conditions. The validity of such models is ultimately reflected in their ability to accurately predict the behaviour of active ingredients at the corresponding in vivo barrier.

Especially the blood-brain barrier has gained more importance in the last years since neuropathological symptoms are on the advance, due to more elderly people in our population. There is a greater need to check the brain availability of substances, which was done until now in very detailed animal experiments. Bartmann et al. (2001) reported a very sophisticated artificial blood-brain-barrier model consisting of co-cultures of capillary endothelium cells and astrocytes, which gave good correlations with in vivo data.

\section{4 $3 R$ principles in antibody production}

There is hardly a discipline in basic biomedical research that can do without the use of specific antibodies. As the production of antibodies in animals was often not considered an animal experiment, it went almost unnoticed by the regulatory authorities and the practice of cruel forms of immunisation, e.g. in the ball of the foot or using Freund's adjuvant (FA), are still practiced in some countries. Often, the regulatory authorities do not know about available alternatives and believe the scientist's statement that the method is necessary without requiring proof that one of the many established refinement methods was attempted.

It should also be considered that extremely high antibody titres are often not required and it is also often overlooked that the antibody titre is not the true control for the success of the immunisation, because the real goal is to have immunised spleen cells for a fusion to become hybridoma cells. Ferber et al. (1999) showed that the alternative adjuvant pApU (polyadenylic-polyuridylic acid) can have a better fusion efficiency than FA (see Fig. 8) but has a much lower histopathology score.

\subsubsection{A success story: The in vitro production of monoclonal antibodies}

Antibodies are very useful tools to detect different structures in basic research, clinical diagnostics and also therapy. Monoclonal antibodies (mAb) were first described by Köhler and Milstein (1975) and were originally produced in ascites mice. Ascites induction causes very severe pain and distress to the mice used.

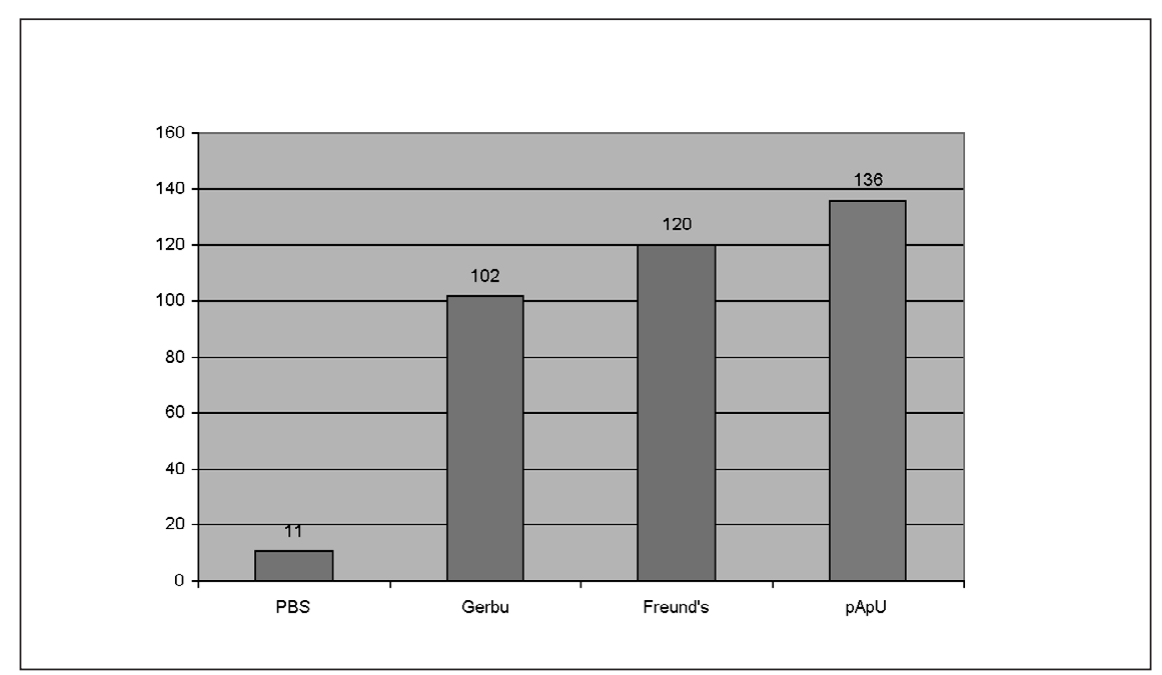

Fig. 8: Fusion efficiency quantified as number of growing clones/fusion (see Ferber et al., 1999)

In most cases, non-animal or in vitro alternatives can be employed to reduce or eliminate the use of animals for $\mathrm{mAb}$ production. After a number of years of single national initiatives to ban the production of monoclonal antibodies using the extremely painful in vivo method (ascites mouse), an ECVAM workshop in 1997 brought the break-through (Marx et al., 1997). It could be proven that there are enough in vitro laboratory methods to cater for all requirements regarding quantity and quality. Meanwhile lists of manufacturers who produce monoclonal antibodies solely by in vitro methods can be found at www.frame.org.uk/ ardfmab.htm. The painful method of production using the ascites mouse is now only performed in backward countries without any legal animal protection. The number of animals spared is enormous, millions of mice per year.

Hendriksen (1998) therefore discusses a ban of the ascites method in the whole of Europe, as is the case de facto in Germany, Switzerland and the Netherlands. He writes that "prohibition of the use of animals in the production of mAbs is recommended, except when the replacement in vitro methods prove to be insufficient, and in a limited number of other well documented cases, such as an exceptional need for an emergency therapeutic application". He emphasises the establishment of core facilities for in vitro $\mathrm{mAb}$ production.

Even in the USA, where mice are not protected under animal welfare legislation, the production of monoclonal antibodies in ascites mice is no longer "state of the art" and governmental agencies since 2000 do not give money to research projects in which ascites mice are used, so that one can speak of a de facto ban.

\subsubsection{Alternatives to come: The recombinant antibody families}

At the Linz 1995 congress and at the $3^{\text {rd }}$ World Congress in Bologna, Stadler (1995) and Stadler et al. (2000) described the replacement of monoclonal antibodies by recombinant antibodies. This technique has developed into a useful approach to get antibodies of nearly all specificities. It is based on the cloning of light and heavy immunoglobulin chains, which are subsequently recombined in a 
bacteriophage vector. The source of the immunoglobulin-variable genes can be the genome of an animal or a human, immunised or after normal exposure or disease.

Furthermore, hypervariable regions of the immunoglobulins can also be artificially inserted, so the generation of synthetic antibody libraries is possible. The advantage of the methodology lies in the fact that these antibody libraries have a complexity of $10^{8}$ in the case of immune libraries or $10^{12}$ in the case of synthetic libraries, a much greater range than can be isolated by hybridoma technology. Stadler writes that the new technology still needs a higher degree of laboratory skills than the production of monoclonals. He also considers that recombinant antibodies cannot end the use of animals for the production of antibodies completely. Antibody production that assists the understanding of pathophysiological processes in animals could not be feasibly performed in humans. And animals would still be needed for reagents that are not immunogenic in humans or that would be unethical to use in humans. But these are minor exceptions. The future of antibody production in basic research possibly brings a nearly complete renunciation of animal use in the next 10-15 years - if scientists support these developments. This may bring a reduction in the numbers of laboratory animals in dimensions not known before. Estimations tally a number of several million animals per year worldwide.

\subsubsection{In the meantime: Refinement - the IgY antibody}

Immunisation of chickens and extraction of antibodies from egg yolk belongs to the alternative methods since the animal suffering is reduced by non-invasive antibody-sampling (Gassmann et al., 1990; Schade and Hlinak, 1996). One year later Schade et al. (1997) wrote "It has been known for over a century that specific antibodies can be extracted from the eggs of immunised chickens. However, it was only when animal welfare became a subject of public debate that the chicken was considered as an alternative source of antibodies due to the possibility of noninvasive antibody sampling. Unfortunately, the welfare of animals alone is not sufficient to attract the interest of scientists, it is therefore important to demonstrate to potential users that avian antibodies can be used successfully in a variety of scientific investigations". A considerable quantity of antibodies can be obtained from one chicken. This method is quick and simple to perform. The animal welfare advantage is that the chicken must not be bled as the antibodies can be isolated from the eggs. But as the chicken still has to be immunised, it is not an animal-free method. ALTEX dedicated an entire supplement to the production of avian antibodies (ALTEX, 1996). But it should be reiterated that there is no refinement in the production of avian antibodies if the chickens are not held in an absolutely chicken-friendly environment, which allows them to live out all their behavioural specialities (Scharmann, 1996). And, of course, it is not a refinement method if adjuvants are used which cause adverse effects in the chicken or which are given by an inhumane route (i.e. Freund's adjuvant given intramuscularly or intraperitoneally).

\subsubsection{Alternative adjuvants}

Current immunisation procedures are often based on habit and tradition. Very often the "hard" Freunds adjuvant is used but "soft" alternatives would also do (a list of "soft" alternatives is given in Leenars et al., 1999, Appendix 2). The procedures need to be harmonised to guarantee a maximum of refinement worldwide. Great consideration should be given to the appropriate housing of immunised rabbits. There is no scientific reason to lock these animals (usually rabbits) in cages. Keeping them on the ground in small groups increases their quality of life significantly.

\subsection{In vitro techniques in parasitology}

Almost the most forgotten animals in science are those not used to produce scientific results but "only" to multiply certain organisms in the field of parasitology. Animals used for the growth of parasites suffer much more than generally believed. Great efforts are required to promote the development of in vitro cultures. These are often not undertaken

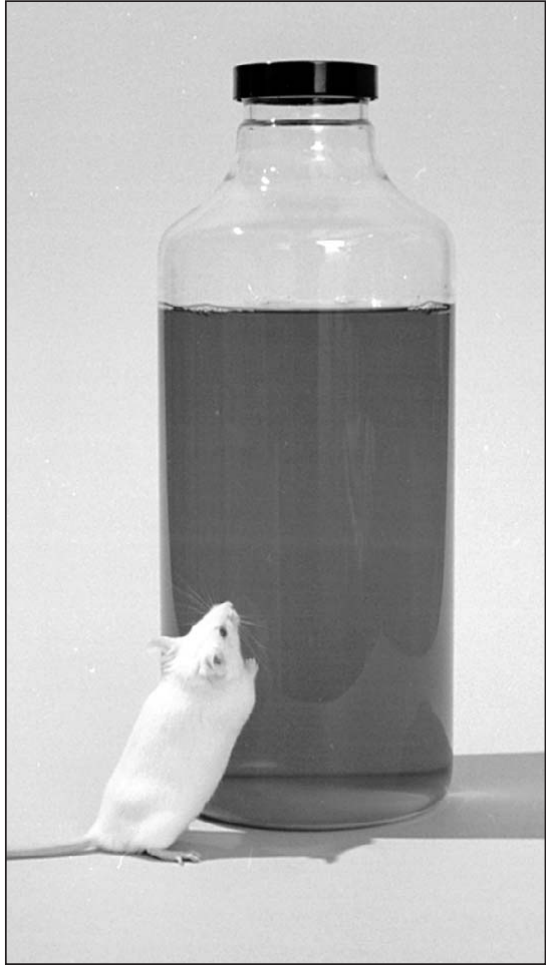

for reasons of convenience. The "replacement" potential is very large.

Falcone et al. (1995) described the in vitro cultivation of Brugia malayi, a parasitic nematode that causes human lymphatic filariasis. Kuhnert (1996) described results on in vitro feeding of the hard ticks Ixodes ricinus, Boophilus microplus, Amblyomma variegatum and Amblyomma hebraeum with bovine blood and presented an in vitro test for systemic acaricides. Larvae of B. microplus were bred to the unfed adult stage. Females gained half of the natural body mass and laid eggs. The lifecycle of A. hebraeum was completed in vitro. The reproductive capacity of most adult tick species was strongly impaired, possibly as a consequence of the low quality of the blood. This method offers new in vitro possibilities for tick rearing as well as for tests with systemic acaricides, anti-feedants and repellents and allows experiments on the transmission of pathogens.

In later experiments Kuhnert et al. (1998) showed the successful feeding of males and females of $A$. hebraeum in a partly automated, thus essentially maintenance-free, in vitro system. The feeding data did not differ significantly from 
that achieved with bovine hosts.

Matthes and Hiepe (1996) reported on the laboratory breeding of lice, fleas and other bloodsucking arthropods. To date, it is not possible to replace rabbits as natural blood sources for breeding lice colonies (Pediculus spp.). A socalled "artificial dog" has been developed for in vitro breeding of cat fleas (Ctenocephalides felis). This may replace numerous animals used as hosts of laboratory flea colonies in pharmaceutical companies and other research laboratories.

\subsection{In silico alternatives}

Like key and keyhole, biologically active substances coming into contact with receptors on cell surfaces either fit and have an effect or do not. Vedani (1994) is one of the pioneers in this field who developed a model, which allows the calculation of effects even if one of the reacting partners, the receptor, is not known. This technique is called pseudoreceptor modelling, and was a very original concept within the field of Computer-Aided Drug Design. It allows the reconstruction of the three-dimensional structure of an unknown bioregulator based on the structures of its ligands (known bioactive compounds). It combines present techniques but significantly extends their possibilities by the generation of an explicit receptor model. This model may subsequently be used for the qualitative prediction of the binding strength of novel drug molecules. The relevance of pseudoreceptor modelling for reducing and replacing animal models is given by the fact that the technique can be applied under circumstances where little or no information is available on the true biological receptor, a situation where to date only in vivo techniques were promising. As a first technique, pseudoreceptor modelling allows the screening of potential drug molecules binding to an unknown bioregulator.

The newest project of this group is the call for a co-operation to establish an internet laboratory for predicting harmful effects triggered by drugs, chemicals and their metabolites (Vedani and Dobler, 2001). Presently, the database of Vedani and Dobler includes models for only five biological targets. It will be extended continuously to include surrogates for any bioregulator known or presumed to mediate harmful effects. Free access to this virtual laboratory shall allow any interested party to estimate the harmful potential of a given substance prior to its synthesis. See also www.biograf.ch.

QSAR methods have become very important in pharmacological basic re-



Fig. 9: Development of laboratory animal numbers at a German chemistry plant search. They have contributed significantly to reducing the animal numbers in the pharmaceutical industry. These methods are faster, cheaper and more efficient. Possible metabolic products of the test substances must also be considered in the QSAR methods in future. It is to be hoped that the side effects of substances will eventually be predictable. The potential for reduction of experimental animal use by QSAR methods lies in the region of millions of animals per year. According to an EU press release (16 October 2003), the introduction of QSAR methods could substitute for animal experiments costing 950 million Euro in the EU programme REACH alone. According to a German chemical company, the introduction of QSAR methods could lead to a reduction of the experimental animal numbers by a further $30 \%$ within a few years. Already the use of isolated organs had previously also reduced the animal numbers by $30 \%$ (see Fig. 9).

\section{Further developments and resources for information systems on alternatives}

The importance of databases to find possible alternatives easily and fast can hardly be overestimated. Only with such databases can the regulatory authorities be given the right instruments to make competent decisions about the approval of animal experiments. However, simple lists of alternatives for a specific procedure are not enough. Comments on the feasibility and relevance of the alternative methods must be added. While the accepted methods for mandatory drug and chemical testing are eventually set down in pharmacopoeias or OECD guidelines, these databases represent the only possibility to promote the use of $3 \mathrm{R}$ methods in basic research.

In 2000, ZEBET (German Centre for the Documentation and Validation of Alternative Methods) at the Federal Institute for Consumer Health Protection and Veterinary Medicine $(\mathrm{BgVV})$ put the ZEBET-database on alternative methods to animal experiments on the internet via DIMDI, the German Institute for Medical Documentation and Information 
(www.dimdi.de) (Grune et al., 2000). Access to the database is free, moreover DIMDI's complete service is available to visitors of the ZEBET-database. The ZEBET-database contains documents on alternatives to testing in animals, which have been carefully evaluated by ZEBET's staff according to the 3R concept. In addition, the ZEBET-database provides information on the current stage of development and validation of a method and on its acceptance for either scientific or regulatory purposes. Each document is characterised by the following criteria: the title of a method, keywords, assessment, summary and bibliographic references. To search DIMDI's-database and host system "grips" soft- ware must be used. Currently about 125 alternative methods meet the criteria of the ZEBET-database. International fellow organisations, e.g. FRAME (Fund for the Replacement of Animals in Medical Experiments) in the UK and CAAT (Johns Hopkins Center for Alternatives to Animal Testing) in the USA, have established links on their websites to provide visitors free access to the ZEBETdatabase.

Similarly, the European Centre for the Validation of Alternative Methods (ECVAM) has established a database on alternatives, which was recently released (http://ecvam-sis.jrc.it/).

A number of amendments with respect to databases on alternatives might be envisaged for the future:

- The different databases should be interlinked.

- They should include Standard Operation Protocols in collaboration with the developing laboratory in order to ease taking over the method.

- The databases should be extended to promising approaches which are not yet evaluated.

- A search in the databases should become mandatory when asking for approval of an animal experiment.

- Guidance for searching these databases should be developed.

Furthermore, it is suggested to establish in parallel databases, which list drawbacks and limitations of in vivo models. Similar to gene banks, free entries of comments and additional infor- mation from scientists should be possible, since limitations and shortcomings are usually underreported.

A new study which should analyse how the results of a research for publications on alternatives indicated that the current indexing systems do not provide the required information. Not all the relevant information is indexed under "alternative methods". So the participants of a workshop held at ZEBET in Berlin 2004 developed recommendations to develop suitable search strategies on alternative methods for scientists (Grune et al., 2004).

\section{Discussion}

\subsection{Does freedom of science hamper $3 R$ methods?}

Contrary to the animal experiments required officially, which are listed and described clearly in the pharmacopoeias, DIN / ISO instructions and OECD guidelines, in basic research we hardly ever find any laboratory that carries out the identical animal experiment as an another laboratory, even if working on the same subject. In the regulatory animal experiments, the solution to overcome animal consumption is clearly defined, i.e. the acceptance of a valid alternative method, but in basic research, scientists mostly do not even know what the term validation means. This was one of the results of an assessment of research funding for replacement of animal experiments in basic research (Gruber et al.,1996).

Only a few techniques like the in vitro production of monoclonal antibodies (see 4.4.1) have really succeeded. Mostly, the application of the alternative technique only takes place in the institution in which it was developed; more often the application of the alternative method in this institution is given up after changing employees. This development must be paid increasing attention especially by the allocation of research means. Nothing and nobody can force a scientist in basic research to develop an alternative method or to apply a method developed elsewhere. Smallest differences can always be found in the researched material or in the collected data, which from a le- gal point of view allow the continuation of an animal experiment.

Where are the difficulties in basic research, why are animal tests not diminishing like in the field of applied sciences? How shall validation work in basic research? Hartung and Spielmann (1995) wrote about the experience of recent attempts to validate alternative methods to animal experiments, pointing to the differences in the field of safety testing (toxicology) and identification of putative drugs (pharmacology, basic research) and stating that these require different validation strategies. In the end, it is most important in basic research that the alternative method is relevant and more efficient than the respective animal experiment. It does not have to be the exact mirror of the animal experiment, which is usually required for safety tests, where the fear is that a change in the method will increase the risk for people. Thus, beside availability and visibility of the method, which is best achieved when marketed by a company, the limitations of the animal experiment and the advantages of the replacement must be made clear. Therefore, on the one hand systematic reviews of the methods are required, ideally made available both in paper form and in a database, and the animal experiment itself should be included and reassessed in every validation study. There have already been examples in which the gold standard, i.e. the animal experiment to be replaced, turned out to be less golden than expected. If possible, this should be done without carrying out additional animal experiments, by employing either historical data or taking advantage of animal experiments which are currently carried out anyway and optimally running the in vitro test in parallel on the same material. If neither can be achieved, this might indicate that the respective animal experiment is seldom done or that there is little willingness to replace it by the user - either should be an indicator that there are more pressing areas for the development of alternatives.

Freedom of research and teaching is embodied in the German Constitution (the European Constitution is expected to contain at least a paragraph on the freedom of research). Nevertheless, freedom of science in most cases is only written 
on the paper, even at universities. The arguments for the freedom of science are based on assumptions, which largely no longer correspond with the social reality of the research. The respective article in the constitution, once promulgated in order to protect science from governmental arbitrariness, still implies a powerful state and a delicate plant called science. Meanwhile, rather powerless states are entirely helpless when faced with the innovations of an international science. Bayertz (2000) writes (literal translation): "The delicate plant called science has grown into a massive tree which throws its shadows on the entire community. Today, the community is influenced and changed more by scientific-technical innovations than by political decisions. Similar to the economy (and in a parallel development) it has become a democratically uncontrollable social-political power. The key problem and challenge lies in the control of science as a subsystem of modern society. Not only, but to a great extent, finding a solution for this problem will determine whether the social evolution grasps humanity like a natural force and drags it along or whether this evolution is steered by sensible and humane criteria. Currently, there are few indications that this problem can be solved, either theoretically or practically."

In case of animal experiments the $3 \mathrm{R}$ principle has offered a compromise between science and society with regard to animal use for many years. Unfortunately, this principle is not even mentioned in the memorandums of large German scientific societies. A change in attitude is required following the recommendations of the European Science Foundation of the year 2000 in order to promote the application of the $3 \mathrm{R}$ principle.

But there are exceptions in which science decided to forego some of the basic rights of its freedom. In Zurich the academic teachers decided to waive experiments involving excessive suffering of animals, even when useful results can be expected. This is a new attitude in basic research. Details can be found in the "List of animal tests which are no longer allowed at institutes of higher learning in Zurich" (Task force for animal welfare questions at Zurich University and ETH,
Dietz et al., 1997). Following a series of intensive discussions, the members of the task force and representatives of Swiss Animal Welfare Organisations agreed on a so-called "negative list". Operations and treatments listed therein are not to be performed any longer, even if a high gain of scientific knowledge is to be expected. This is in accordance with paragraph 4.6 of the "Ethical principles and guidelines for scientific animal testing" of the Swiss Academy of Medical Sciences and the Swiss Academy of Natural Sciences which states that animal testing must not be performed if such testing leads to severe suffering of animals. This list is updated at regular intervals.

\subsection{Animal welfare in the constitutional law}

After several frustrating attempts animal welfare has now been given constitutional rank in Germany. However, this does not alter the fact that there is a primacy of the freedom of basic research over animal welfare. According to the opinion of the authors it would now be much more effective to authorise freedom of research and teaching with a legal provision. A mention of animal welfare in Basic Law in the medium-term does not yet mean basic rights for animals. Although legal conflicts on controversial animal experiments (e.g. the Berlin judgement) could turn out differently, more and more decisions on individual cases would have to be enforced. A provision in that point is necessary which gives the animal welfare law the meaning that it should have according to the opinion of the legislator. In any case, a legal provision should be inserted in article 5/III of the constitution of the German Federal Republic supplemental to the mention of animal welfare.

In Switzerland animal welfare has had constitutional rank for many years. In legal practice, this has not resulted in obvious improvements. In Switzerland different to Austria and Germany - the animal was an object until 2002. In the Swiss animal law the vertebrate animal is protected from pains, sorrows, injuries and fears, but its life is not protected. The killing even of a primate is not against the law as long as it is done properly.

1998 Caspar published an article "An- thropocentrism versus Pathocentrism On the Integration of Animal Protection into the System of Safeguarding Basic Democratic Rights". Modern animal protection laws must be firmly rooted in a decisive pathocentric (similar treatment for similar suffering capacity) fundamental declaration. In accordance with this, it is not a case of protecting human interests concerning a particular way of treating animals but rather of protecting animals from the exploitation interests of humans. In order to attain a balance between animal protection and the laws pertaining to animal use, the regulations governing pathocentric animal protection must rest on a legal foundation backed by constitutional law. In the final instance, a statutory framework either in the form of an objective legal obligation or - better still - in the form of subjective-legal animal protection must be considered. The latter solution has the advantage that the law enforcement deficits of the authorities responsible for animal protection may be supplemented by the fiduciary safeguarding of animal rights by a third party.

In non-European countries animal rights are frequently discussed very intensively but are often tied up with certain cognitive abilities of the animals (primates), a debate that rather appears in the light of an extended speciesism discussion. In those countries terms like the "dignity of the creature" are not understood. It is astonishing that some US societies of science now as before refuse to give rodents and birds the "status of an animal" at all, fearing that these laboratory animals would then have to be counted in statistical surveys. Superficially it is argued that this is a financial problem (Goldberg, 2002).

\subsection{Importance of representative statistics on animal experimentation}

Revised tables for the collection of statistical information on the number of animals used in experiments and for other scientific purposes in the European Union are finally available (Casati and Hartung, 2003). The new tables to be used for future statistics on animal experiments in the European Union presented by the European Commission have been significantly extended and improved in 
comparison with the old ones. Several categories of little relevance and unclear expressions have been revised. However, some important data (inter-alia categories for pain and distress as well as for several purposes of use; the origin of some animal species; types of institutions) are still not required, even though they are highly relevant with respect to animal welfare aspects and must be regarded as indispensable for a targeted application of the statistics to set priorities concerning the $3 \mathrm{Rs}$.

\section{Solutions, medium and long- term development}

\subsection{Harmonisation}

Standards of animal welfare are very different in various countries: While science is a very international business, the standards for reasonable and humane control of animal use in basic research have been little harmonised yet. The situation that Switzerland calls for "the dignity of (all) animals" and that in the US birds, mice and rats are not even considered to be animals is unsatisfactory. The majority of European countries with a more humane animal welfare legislation, however, should not be brought down to a lower harmonised international level. In order to implement fully humane practices in science, it is necessary to join the progressive forces of all countries including those lagging behind. Self-restriction of science could be a driving force of these unifying efforts.

In the next years, it should be possible to develop a standardised practice for humane treatment of laboratory animals within the EU. In addition, the new instructions of the European Science Foundation of the $9^{\text {th }}$ of September 2000 have raised the hope that basic research will at least accept the $3 \mathrm{R}$ principle. This may however only be understood as a transitional phase. In the long-term, only the superiority of in vitro tests over animal experiments will lead to their application (see below). The shortcomings and failures of specific animal experiments in basic research have to be stressed in order to provoke rethinking. It will take generations of scientists to change the general attitude as to the value of animal experiments.

It is of critical importance that research is not exported to countries with less strict regulations with regard to animal welfare. Where this cannot be achieved by harmonisation, binding rules set by authorities and funding bodies must ensure this. It is not acceptable that standards are circumvented by "the help of friends abroad".

\subsection{Increasing the quality of in vitro methods}

The most convincing argument for a scientist to employ a given method is its relevance and the likelihood of convincing results. Quality assurance is therefore of utmost importance. Based on this idea, the initiative was taken to establish a guideline of Good Cell Culture Practice (GCCP). In contrast to Good Laboratory Practice (GLP), which is broadly established in industry and is hardly feasible in academic research, only the minimum requirements for quality control are defined. In 1999, on occasion of the $3^{\text {rd }}$ World Conference on Animal Use and its Alternatives in the Life Sciences, a workshop and subsequent plenary session endorsed a declaration towards the establishment of GCCP. A taskforce was installed which worked on the drafting of such guidelines. The respective taskforce report is available (Hartung et al., 2002). The idea shall be promoted by an ECVAM workshop to develop the guidelines further. In a broader sense, this idea of quality control leverages the experiences made in validating alternative methods for the whole field of biomedicine. Never before have similar efforts been undertaken to validate in vitro test systems and establish both reproducibility and relevance. This concept parallels the development towards evidence-based medicine in the clinics: Only by proving the validity of results - whatever effort it takes - meaningful science can be achieved.

\subsection{Promoting the use of animal-free methods}

In many areas the field calls for in vitro methods; an earlier analysis of the area of pharmacology by Hartung and Wendel
(1998) came to a positive overall assessment: Asking the question "is replacement of animal experimentation in pharmacology a goal or a social constraint, utopia or reality?", the authors come to the conclusion that "the judgement comes clearly in favour of the alternative methods, needless to say in a field where most animal experimentation occurs." They further "conclude that the discipline profits considerably from switching to in vitro models, even though the complete replacement of animal experimentation would be unrealistic".

Science follows the mechanisms of the market, since it aims to achieve the results with least investment with regard to resources (personnel, consumables, time, equipment). The price for animal experiments might thus be raised considerably to reduce animal experimentation. This might include animal welfare requirements, required training of personnel, delays in approval of animal experiments and bureaucracy of approval.

The availability and visibility of alternatives must be increased by promoting technology transfer. So far, the term is predominantly employed for transfer of methods from academia to industrial use. The Steinbeis technology transfer centre InPuT (In vitro Pharmacology and Toxicology) in Konstanz, Germany, has shown over the years that this can be achieved efficiently and profitably. In case of basic research, similar technology transfer must be enabled, but here public sponsoring is required in contrast to industrial financing, which is more than willing to pay for a relevant method. Databases with indispensable crosschecks for the availability of an alternative when asking for approval to carry out an in vivo study must be implemented. Here guidance how to search the databases properly should be developed. Setting the respective alternative into practice should be aided by providing laboratory infrastructure as well as detailed information on the respective method, e.g. by making available detailed SOPs or training courses.

Journals play a critical role in directing science and funding bodies since they can urge the scientist to apply or not apply certain standards. A binding declara- 


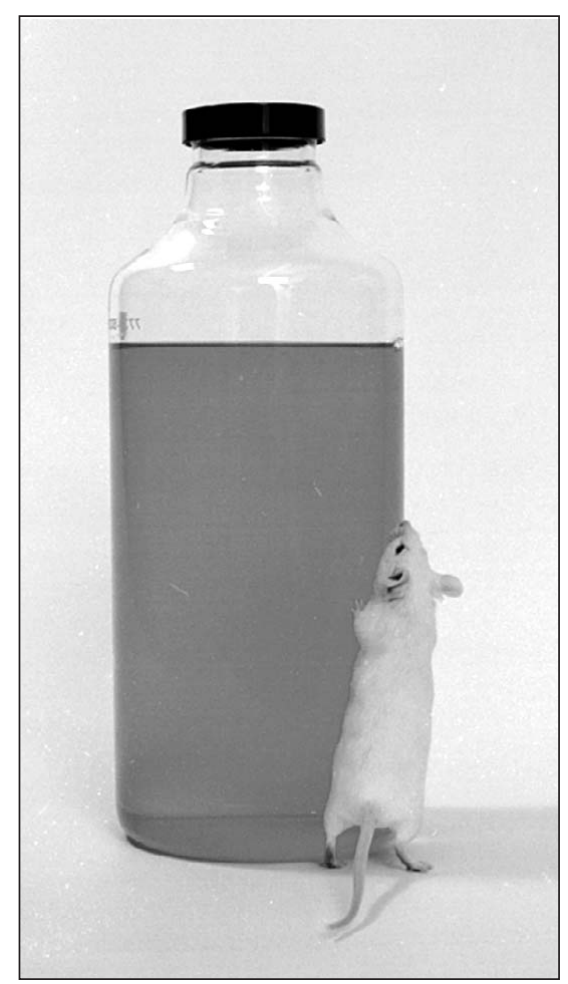

tion similar to the Declaration of Helsinki for clinical trials on patients and volunteers, which defines the standards for optimised and minimal animal use is necessary. Such a consensus declaration would go far beyond a GCCP guideline; it might be based on the Bologna declaration on the $3 \mathrm{R}$ principle and could be created on occasion of a future conference of this series.

\subsection{The pipeline}

The pipeline is a term used in pharmaceutical companies for the products under development and considered close to the market. For alternative methods in some areas such as chronic toxicity, the pipeline is mostly empty. Still, the development of alternatives from scratch in areas of need (e.g. cosmetics, chemicals, chronic toxicity, neurotoxicity, immunotoxicity) should be encouraged by offering funding and awards, or the gap between development and validation of methods already available has to be closed. It is little tempting for a researcher to standardise, optimise and critically review his/her experimental model. Too often this will not lead to publishable data but to a questioning of the results gained so far. In science, where "publish or perish" is a common saying, too little attention is paid to the proper evaluation (not even asking for validation) of the methods employed. A biometrical analysis to establish the opportunities and limitations of a test is hardly ever carried out for any method described in a scientific paper. In theory, this is a prerequisite for the interpretation of results, in practice, nobody cares, which might be the reason why so many results reported cannot be reproduced and vanish over time. Since these steps of evaluation and optimisation, which are required for an increase in the quality of the performed science, are exactly the steps to be carried out between development and validation of a test, both aims work hand in hand. Seen the other way around, this is what the field of alternative methods has to offer basic science: a proper concept of how to establish the reproducibility and the relevance of a method. Applying this in a broader form will automatically fill the pipeline, making the gap towards validation smaller on the one hand and on the other hand, improving the reliability and thus relevance of the method and making its application more likely.

\subsection{Education}

Concepts are best furthered from teacher to pupil. At a stage when collecting ideas, which will last a lifetime, i.e. when the scientific mind is formed during the early years of university, the concepts of alternatives to animal experiments, relevance and quality control must be implanted. This purpose is served best by establishing the subject in the study curricula of the life sciences. A chair on alternatives might be a first step towards developing and implementing the concepts and to optimising the respective educational offers (Wendel, 2002). The educated mind of future academics is the best messenger to spread these ideas when these young people take over responsibility in their profession and further develop the body of these ideas. See also the following chapter by Gruber and Dewhurst.

\section{References}

ALTEX Supplement (1996). DottersackAntikörper, Egg Yolk Antibodies, IgYTechnology. ALTEX 13 Suppl., 1-85.

Anderson, R., Balls, M., Burke, M. D. et al. (2001). The establishment of human research tissue banking in the UK and several western European countries. The report and recommendations of ECVAM workshop 44. ATLA 29, 125-134.

Arnhold, S., Andressen, C., Hescheler, J. und Addicks, K. (1998). Mikrokinematographische Neurodifferenzierungs- und Neurotoxizitätsstudien an einem in vitro Modell unter Verwendung embryonaler Stammzellen der Maus (Microcinematographic studies on neurodifferentiation and neurotoxicity in vitro using mouse embryonic stem cells). ALTEX 15, 59-66.

Ast, I., Heydeck, D., Mothes, E. and Christ, B. (2001). Standardized in vitro electrophysiologic measurements using isolated perfused porcine hearts - assessment of QT interval alterations. ALTEX 19, 3-8.

Balls, M. (1995). The use of non-human primates as laboratory animals in Europe: moving toward the zero option. ATLA 23, 284-286.

Balls, M. and Karcher, W. (1995). The validation of alternative methods. ATLA 23, 884-886.

Balls, M., Goldberg, A. M., Fentem, J. et al. (1995). The Three Rs: the way forward. The report and recommendations of ECVAM workshop 11. ATLA 23, 838-866.

Balls, M. (1999). The biomedical sciences and the need for less in-humane procedures. In C. F. M. Hendriksen and D. Morton (eds.), Humane endpoints in animal experiments for biomedical research (1-4). London: The Royal Society of Medicine Press ltd.

Bartmann, A., Sladek, M., Schimpf, T. et al. (2001). Die Blut-Hirn-Schranke in vitro und ihre Anwendung: Standardisierung, Validierung und in vitro-/in vivo-Korrelation (The blood-brain barrier in vitro and its applications: standardisation, validation and in vitro-/ in vivo correlation). ALTEX 18, 181 (abstract). 
Bateson, P. (1986). When to experiment on animals. New Scientist, 20 February, 30-32.

Bayertz, K. (2000). Drei Argumente für die Freiheit der Wissenschaft (Three arguments for scientific freedom). ALTEX 17, 59-65.

Blaauboer, B. J., Boobis, A. R., Castell, J. V. et al. (1994). The practical applicability of hepatocyte cultures in routine testing. ATLA 22, 231-241.

Bottrill, K. (2002). A Guide to searching for alternatives to the use of laboratory animals. http://www.frame.org.uk/ Guide/index.htm

Buesen, R., Visan, A., Genschow, E. et al. (2004). Trends in improving the embryonic stem cell test (EST): an overview. ALTEX 21, 15-22.

Bundesbericht Forschung (2004). Bundesministerium für Bildung und Forschung, www.bmbf.de/pub/bufo 2004.pdf

BVET (1994). Einteilung von Versuchen nach Schweregraden vor Versuchsbeginn (Belastungskategorien). Information Tierschutz 1.04. http://www. bvet. admin.ch/0_navigation-d/0_index-intern.html

Casati, S. und Hartung, T. (2003). Dritter Report der EU zu Versuchstierzahlen liegt vor (Third report of the EU on experimental animal numbers). ALTEX 20, 93.

Caspar, J. (1998). Anthropozentrismus versus Pathozentrismus - zur Stellung des Tierschutzes im System des grundrechtlichen Freiheitsschutzes (Anthropocentrism versus pathocentrism on the integration of animal protection into the system of safeguarding basic democratic rights). ALTEX 15, 205 208.

Combes, R., Balls, M., Curren, R. et al. (1999). Cell transformation assays as predictors of human carcinogenicity. ATLA 27, 745-767.

Delpire, V. and Balls, M. (1998). ECVAM Workshop über die Verwendung transgener Tiere in der EU. Ein Überblick (Use of transgenic animals in the European Union). ALTEX 15, 23-26.

DFG (1971). Mitteilung I der Kommission für Versuchstierforschung. Grundinformationen über Versuchstierfragen. Bonn: DFG.
DFG (1981). Mitteilung III der Kommission für Versuchstierforschung. Tierexperimentelle Forschung und Tierschutz. Boppard: Harald Boldt Verlag. DFG (1991). Mitteilung IV der Senatskommission für Versuchstierforschung. Novellierung des Tierschutzgesetzes 1986. Informationen für den Forscher. Weinheim: VCH.

DFG (1993). Denkschrift der Senatskommission für tierexperimentelle Forschung. Tierversuche in der Forschung. Weinheim: VCH.

DFG (1996). Deutsche Forschungsgemeinschaft. Forschungsfreiheit. Ein Plädoyer für bessere Rahmenbedingungen der Forschung in Deutschland. Weinheim: VCH.

Dietz, V., Eppenberger, H. M., Glaser, D. et al. (1997). Liste nicht mehr zulässiger Tierversuche an den Zürcher Hochschulen (List of animal tests which are no longer allowed at institutes of higher learning in Zurich). $A L$ TEX 14, 61-62.

Doehmer J. und Jacob J. (1994). Gentechnologisch konstruierte V79 Zelllinien in Kombination mit chemischanalytischen Verfahren als Ersatz und Ergänzung zu Tierversuchen (Genetically engineered V79 cell lines in combination with analytical-chemical procedures for replacing and refining animal experimentations). ALTEX 11, 141-147.

Doehmer, J. (2001). Moderne Arzneimittelentwicklung mit molekular- und zellbiologischen Methoden (Modern drug development by molecular and cellbiological methods). ALTEX 18, 912.

Falcone, F. H., Schlaak, M. und Haas, H. (1995). In vitro Kultur von Brugia malayi, einem Erreger der lymphatischen Filariose beim Menschen (In vitro cultivation of Brugia malayi, a parasitic nematode that causes human lymphatic filariasis). ALTEX 12, 179187.

Ferber, P. C., Ossent, P., Homberger, F. R. and Fischer, R. W. (1999). The generation of monoclonal antibodies in mice: influence of adjuvants on the immune response, fusion efficiency and distress. Laboratory animals 33, 334350.

Finking, G., Wolkenhauer, M., Lenz, C. and Hanke, H. (2000). Post-injury ex vivo model to investigate effects and toxicity of pharmacological treatment in rings of rabbit aortic vessels. ALTEX 17, 67-74.

Flecknell, P. A. (1994). Refinement of animal use - assessment and alleviation of pain and distress. Laboratory Animals 28, 222-231.

Flecknell, P. A. (1996). Laboratory Animal Anaesthesia: An Introduction for Research Workers and Technicians. $2^{\text {nd }}$ ed. London: Academic Press.

Flecknell, P. and Waterman-Pearson, A.(2000). Pain Management in Animals. London: Harcourt Health Sciences.

Flury, A. (1999). Sind operative Eingriffe in Gehirne lebender Primaten in der Grundlagenforschung moralisch vertretbar? (Is brain surgery on primates in basic research morally acceptable?). ALTEX 16, 267-270.

Gärtner, K. (1999). Cage enrichment occasionally increases deviation of quantitative traits. Proceedings of the international joint meeting, twelfth ICLAS general assembly \& conference, seventh FELASA symposium, 26-28 May 1999, Palma de Mallorca, Spain. London: Laboratory Animals Ltd.

Gassmann, M., Weiser, T., Tömmes, P. und Hübscher, U. (1990). Das Hühnerei als Lieferant polyklonaler Antikörper (The egg yolk as resource for polyclonal antibodies). Schweiz. Arch. Tierheilk. 132, 289-294.

Genschow, E., Spielmann, H., Scholz, G. et al. (2002). The ECVAM international validation study on in vitro embryotoxicity tests. Results of the definitive phase and evaluation of prediction models. ATLA 30, 151-176.

Genschow, E., Spielmann, H., Scholz, G. et al. (2004). Validation of the embryonic stem cell test (EST) in the ECVAM international validation study on in vitro embryotoxicity. ATLA 32, in press.

Gindorf, C., Steimer, A., Lehr et al. (2001). Markertransport über biologische Barrieren in vitro: Vergleich von Zellkulturmodellen für die Dünndarmschleimwand, die Blut-HirnSchranke und das Alveolarepithel der Lunge (Marker transport across bio- 
logical barries in vitro: comparison of cell culture models for the gastrointestinal barrier, the blood-brain barrier and the alveolar epithelium of the lung). ALTEX 18, 155-164.

Goldberg, A. M. (2002). Use of animals in research: a science - society controversy? American perspectives: animal welfare issues. ALTEX 19, 137-139 and in F. P. Gruber and K. Brune (eds.), ALTEX-Buch 2002. ALTEX 19, Suppl. 2, 41-45.

Gruber, F. P. (1996). Alternativmethoden im Sinne eines Refinements (Alternative methods for Refinement). In F. P. Gruber and H. Spielmann (Eds.), Alternatives to animal experiments (273300). Berlin, Heidelberg, Oxford: Spektrum Akademischer Verlag.

Gruber, F. P. (1998). Transgene Tiere im 3R-Konzept (Transgenic animals and the 3R). ALTEX 15, 26-28.

Gruber, F. P., Günzel, P., Rusche, B. und Schwabenbauer, K. (1996). Studie über die Forschungsförderung des BMBF zur Entwicklung von Ersatzmethoden zu Tierversuchen (Study about the grant programme of the German BMBF for the promotion of alternatives to animal experiments). ALTEX 13, 55-67.

Grune, B., Herrmann, S., Dörendahl, A. et al. (2000). The ZEBET-Database on Alternative Methods to Animal Experiments in the Internet - a Contribution to the Protection of Experimental Animals. ALTEX 17, 127-133.

Grune, B., Dörendahl, A., Skolik, S. und Spielmann (2001). Suchstrategien nach 3R-Methoden im Internet (Search strategies for 3R-methods in the internet). ALTEX 18, 182.

Grune, B., Fallon, M., Howard, C. et al. (2004). Report and recommendations of the international workshop ,Retrieval approaches for information on alternative methods to animal experiments". ALTEX 21, 115-127.

Guan, K., Schmidt, M. M., Ding, Q. et al. (1999). Embryonic stem cells in vitro - prospects for cell and developmental biology, embryotoxicology and cell therapy. ALTEX 16, 135-141.

Gutsche, W. and Stelzner A. (1997). Preselection of potential cancerostatics by automatic analysis of suspended and adherent cells incubated in mi- croplates. ATLA 25, 45-54.

Hartung, T. und Wendel, A. (1993). Entwicklung eines Zellkulturmodells für das Organversagen im septischen Schock (Development of a cell-culture model multiorgan failure in septic shock). ALTEX 10, Nr. 18, 16-24.

Hartung, T. und Spielmann, H. (1995). Der lange Weg zur validierten Ersatzmethode (The sophisticated process of validation). ALTEX 12, 98-103.

Hartung, T. und Wendel, A. (1998). Ersatz von Tierversuchen in der Pharmakologie - Ziel oder Zwang, Utopie oder Realität? (Is replacement of animal experimentation in pharmacology a goal or a social constraint, utopia or reality?). ALTEX 15, 213-215.

Hartung, T., Gstraunthaler, G., Coecke, S. et al. (2001). Good cell culture practice (GCCP) - eine Initiative zur Standardisierung und Qualitätssicherung von in vitro Arbeiten. Die Etablierung einer ECVAM Task Force on GCCP (Good Cell Culture Practice (GCCP) an Initiative for Standardisation and Quality Assurance of in vitro Studies. The Establishment of an ECVAM Task Force on GCCP). ALTEX 18, 75-78.

Hartung T., Balls, M., Bardouille, C. et al. (2002). Good cell culture practice. ECVAM good cell culture practise task force report 1. ALTLA 30, 407-414.

Hendriksen, C. F. M. (1998). A call for a European prohibition of monoclonal antibody production by the ascites procedure in laboratory animals. ATLA 26, 523-540.

Hendriksen, C. F. M. and Morton, D. (eds.) (1999). Humane endpoints in animal experiments for biomedical research. London: The Royal Society of Medicine Press ltd.

Hlinak, A., Marx, U. und Jäger, V. (1994). Experimente zur Herstellung von monoklonalen Antikörpern über das Hühnerei (Production of monoclonal antibodies in chicken eggs). $A L$ TEX 11, 85-91.

Izzi, L. (1998). Anti-endimysium antibodies detection in the celiac disease screening: Indirect immunofluorescence pattern using umbilical cord sections as substrate. ALTEX 15, 141-143. Janusch, A., van der Kamp, M. D. O., Bottrill, K. et al. (1997). Current status and future developments of databases on alternative methods. The report and recommendations of ECVAM workshop 25. ATLA 25, 411-422.

Janusch-Roi, A., Libowitz, L., Grune, B. and Kreger, M. (2000). Alternative methods databases - specialised information sources on alternatives to support scientists and authorities responsible for granting project licences. In M. Balls, A.-M. van Zeller and M. Halder (eds.), Progress in the Reduction, Refinement and Replacement of Animal Experimentation (1731-1736). Amsterdam: Elsevier.

Jones, H. R. P., Oates, J. and Trussell, B. A. (1999). An applied approach to the assessment of severity. In C. F. M. Hendriksen and D. Morton (eds.), $\mathrm{Hu}$ mane endpoints in animal experiments for biomedical research (40-47). London: The Royal Society of Medicine Press ltd.

Köhler, G. and Milstein, C. (1975). Continuous cultures of fused cells secreting antibody of predefined specificity. Nature 256, 495-497.

Kuhnert, F. (1996). Feeding of hard ticks in vitro: new perspectives for rearing and for the identification of systemic acaricides. ALTEX 13, 76-87.

Kuhnert, F., Issmer, A. E. and Grunewald, J. (1998). Teilautomatisierte in vitro Fütterung adulter Schildzecken (Amblyomma hebraeum) (Partly automated in vitro feeding of adult Amblyomma hebraeum (Acari: Ixodidae)). ALTEX 15, 67-72.

Kunzi-Rapp, K., Westphal-Frösch, C., Akgün, N. et al. (1997). Die Chorioallantoismembran des befruchteten Hühnereis als in vivo-Ersatzsystem für die Photodynamische Therapie (The chorioallantoic membrane of the fertilized hen's egg as an in vivo system for photodynamic therapy). In H. Schöffl, H. Spielmann, H. A. Tritthart et al. (Hrsg.), Forschung ohne Tierversuche 1996 (154-158). Wien, New York: Springer Verlag.

Lee, V.-M., Burdett, N. G., Carpenter, T. A. et al. (1998). Magnetic Resonance Imaging of the Common Marmoset Head. ATLA 26, 343-356.

Leenars, P. P. A. M., Hendriksen, C. F. M., Leeuw, W. A. de et al. (1999). The production of polyclonal antibodies in laboratory animals. The report and rec- 
ommendations of ECVAM workshop 35. ATLA 27, 79-102.

Lindl, T., Weichenmeier, I., Labahn, D. et al. (2001). Evaluation von genehmigten tierexperimentellen Versuchsvorhaben in Bezug auf das Forschungsziel, den wissenschaftlichen Nutzen und die medizinische Relevanz (Evaluation of authorised experiments on laboratory animals with regard to the following frame of references: the aim of the research to be carried out, its scientific usefulness and its medical relevance). ALTEX 18 , 171-178.

Lloyd, M. H. and Wolfensohn, S. E. (1999). Practical use of distress scoring systems in the application of humane endpoints. In C. F. M. Hendriksen and D. Morton (eds.), Humane endpoints in animal experiments for biomedical research (48-53). London: The Royal Society of Medicine Press ltd.

Marx, U., Embleton, M. J., Fischer, R. et al. (1997). Monoclonal antibody production. The report and recommendations of ECVAM workshop 23. ATLA 25, 121-137.

Matthes, H.-F. und Hiepe, T. (1996). Zum Stand der in vitro Züchtung von Läusen und Flöhen (The state of in vitro breeding of lice and fleas). ALTEX 13, 130-135.

Mazzotti, F., Sabbioni, E., Ghiani, M. et al. (2001). In vitro assessment of cytotoxicity and carcinogenic potential of chemicals: evaluation of the cytotoxicity induced by 58 metal compounds in the Balb/3T3 cell line. ATLA 29, 601611.

Mench, J. (1999). Defining endpoints: The role of the animal care committee. In C. F. M. Hendriksen and D. Morton (eds.), Humane endpoints in animal experiments for biomedical research (133-138). London: The Royal Society of Medicine Press ltd.

Mertens, C. und Rülicke, T. (2000). Umfassendes Formular zur strukturierten Charakterisierung gentechnisch veränderter Tiere (A comprehensive form for the standardised documentation of transgenic rodents). ALTEX 17, 15-21.

Morton, D. (1999). Humane endpoints in animal experiments for biomedical re- search: ethical, legal and practical issues. In C. F. M. Hendriksen and D. Morton (eds.), Humane endpoints in animal experiments for biomedical research (5-12). London: The Royal Society of Medicine Press ltd.

Motzkus, N., Budinsky, L., Sergejeva, M. et al. (2004). New animal model for stressfree and objective pain research. ALTEX 21, 168-169 (abstract).

Nogueira, A. C., Wagner, S., Riebeling, I. und Klug, S. (1999). Die isolierte normotherme hämoperfundierte Schweineextremität als Modell für pharmakologische und toxikologische Untersuchungen (The isolated normothermic hemoperfused porcine leg as model for pharmacological and toxicological investigations). ALTEX 16, 90-94.

Nussler, A. K., Wang, A., Neuhaus, P. et al. (2001). The suitability of hepatocyte culture models to study various aspects of drug metabolism. ALTEX 18, 91-101.

Olpe, H.-R. und Haas, H. (1985). Der Hippocampus in vitro im Dienste der Epilepsieforschung (The Hippocampus in vitro in the service of epilepsy research). ALTEX 2, No. 2, 5-14.

Palmiter, R. D., Brinster, R. L., Hammer, R. E., Trumbauer, M. E., Rosenfeld, M. G., Birnberg, N. C., and Evans, R. M. (1982). Dramatic growth of mice that develop from eggs microinjected with metallothionein-growth hormone fusion genes. Nature 300, 611-615.

Pittermann, W., Kietzmann, M. and Grosse-Siestrup, C. (eds.) (2000). Proceedings of a Workshop on Isolated Perfused Organs (Hamburg 1998, 36th Scientific Meeting of GV-SOLAS). London: Laboratory Animal Ltd.

Reininger, C. B. (2000). The cell function analyser (CFA) - a physiological in vitro vascular model and potential alternative to animal experiments. $A L$ TEX 17, 115-125.

Rosenbruch, M. (1994). Frühe Entwicklungsstadien des bebrüteten Hühnereies als Modell in der experimentellen Biologie und Medizin (Early stages of the incubated chicken egg as a model in experimental biology and medicine). ALTEX 11, 199-206.

Rosenbruch, M. (1997). Zur Sensitivität des Embryos im bebrüteten Hühnerei (The sensitivity of chicken embryos in incubated eggs). ALTEX 14, 111-113.

Russel, W. M. S. and Burch, R. L. (1959). The principles of humane experimental technique. London: Methuen \& Co LTD. (1992). Special edition by UFAW.

Sadri, F. (2002). Letter to the editors of the proceedings of a workshop on isolated perfused organs. ALTEX 19, 110111.

SAMW und SANW, (1996). Ethische Grundsätze und Richtlinien. Schweizerische Akademie der Medizinischen Wissenschaften, Basel und Schweizerische Akademie der Naturwissenschaften, Bern. ALTEX 13, 3-6.

Sauer, A., Hartung, T., Aigner, J., Wendel, A. (1996). Endotoxin-inducible granulocyte-mediated hepatocytotoxicity requires adhesion and serine protease release. J. Leukoc. Biol. 60, 633643.

Schade, R. and Hlinak, A. (1996). Egg yolk-antibodies, state of the art and future prospects. ALTEX 13, 5-9.

Schade, R., Hlinak, A., Marburger, A. et al. (1997). Advantages of using egg yolk antibodies in the life sciences: The results of five studies. ATLA 25, 555-586.

Scharmann, W. (1996). Tiergerechte Haltung von Legehennen unter Laborbedingungen (Accomodation of laying hens in the laboratory in accordance with animal welfare requirements). ALTEX 13, 136-139.

Scharmann, W. (1999). Physiological and ethological aspects of the assessment of pain distress and suffering. In C. F. M. Hendriksen and D. Morton (eds.), Humane endpoints in animal experiments for biomedical research (33-39). London: The Royal Society of Medicine Press ltd.

Schweizer Akademie der Medizinischen Wissenschaften und Schweizer Akademie der Naturwissenschaften (1996). Ethische Grundsätze und Richtlinien für wissenschaftliche Tierversuche (Ethical principles and guidelines for scientific experiments on animals). ALTEX 13, 3-6.

Seiler, A., Visan, A., Pohl, I. et al. (2001). Etablierung molekularer Endpunkte 
zur Weiterentwicklung des Embryonalen Stammzelltests (EST) mit embryonalen Stammzellen der Maus (Zelllinie D3) (Improving the embryonic stem cell test (EST) by establishing molecular endpoints of tissue specific development using murine embryonic stem cells (D3 cells)). ALTEX 18 (Suppl. Linz 2001), 55-63.

Shoin, K., Yamashita, J., Enkaku, F. et al. (1991). Chick embryo assay as chemosensitive test for malignant glioma. Jpn. J. Cancer Res. 82, 1165 1170.

Siegel-Axel, D. I., Viebahn, R., Betz, E. L. and Barsch, R. (1999). Progress in the research of atherosclerosis and restenosis using an in vitro method: transfilter cocultures with human vascular cells. ALTEX 1999, 117-122.

Stadler, B. (1995). Herstellung von humanen monoklonalen Antikörpern in vitro durch Repertoire-Klonierung (Production of human monoclonal antibodies in vitro by repertoire cloning). In H. Schöffl, H. Spielmann, H. A. Tritthart (Eds.), Research without animal experiments 1995 (301306). Vienna, New York: Springer.

Stadler, B. M., Vogel, M. and Miescher, S. (2000). Recombinant antibodies by

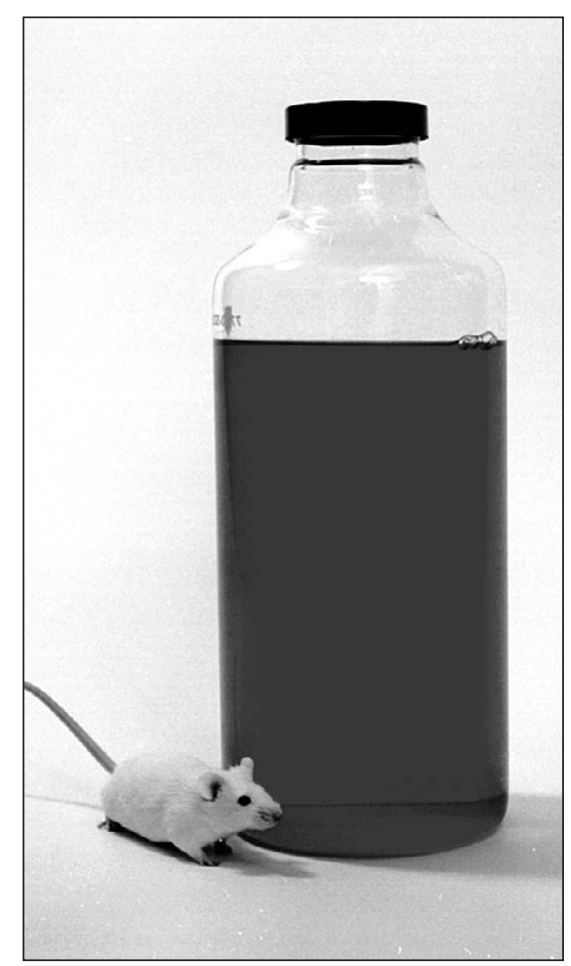

phage display: the end of animal use? In M. Balls, A.-M. van Zeller and M. Halder (eds.), Progress in the reduction, refinement and replacement of animal experimentation (873-878). Amsterdam: Elsevier.

Strübing, C., Wobus, A. M. und Hescheler, J. (1995). Etablierung eines in vitro Modellsystems zur Differenzierung synaptisch verknüpfter Nervenzellen aus pluripotenten embryonalen Stammzellen der Maus (Establishment of an in vitro model system for the differentiation of synaptically coupled neurons from mouse embryonic stem cells). ALTEX 12, 129-137.

Thon, R., Lassen, J., Kornerup Hansen, A. et al. (2002). Welfare evaluation of genetically modified mice - An inventory study of reports to the Danish Animal Experiments Inspectorate. Scand. J. Lab. Anim. Sci. 29, 45-53.

Tritthart, H. A. (1996). In vitro Modelle in der Krebsforschung (In vitro test systems in cancer research). ALTEX 13, 118-123.

Van de Weerd, H. A., Aarsen, E. L., Mulder, A. et al. (2002). Effects of environmental enrichment for mice: variation in experimental results. Journal of Applied Animal welfare Science 5, 87109.

Vedani, A. (1994). Das Konzept des Pseudorezeptors für das pharmakologische Screening (Pseudoreceptor modeling - a tool in the pharmacological screening process). ALTEX 11, 1121.

Vedani, A. and Dobler, M. (2001). Internet laboratory for predicting harmful effects triggered by drugs and chemicals. Concept and call for co-operation. ALTEX 18, 110-114.

Wallace, J. (1999). Humane endpoints in cancer research. In C. F. M. Hendriksen and D. Morton (eds.), Humane endpoints in animal experiments for biomedical research (79-84). London: The Royal Society of Medicine Press ltd.

Wang, T., Nüssler, A. K., Grebe, A. et al. (2002). Three-dimensional co-culture of primary human liver cells in bioreactors for in vitro studies: effects of the initial cell quality on the long-term maintenance of hepatocyte-specific functions. ATLA 30, 525-538.

Weerd, Van de, H. A., Aarsen, E. L., Mulder, A., Kruitwagen, C. L. J. J., Hendriksen, C. F. M. and Baumans, V. (2002). Effects of environmental enrichment for mice on variation in experimental results. Journal of Applied Animal Welfare Science 5, 87-108.

Wendel, A. (2002). Do we need a "chair of alternative methods", and where? ALTEX 19, 64-68.

Wobus, A. M. (2001). Potential of embryonic stem cells. Molecular aspects of medicine 22, 149-164.

Zeilinger, K., Auth, S., Unger, J., Grebe, A., Mao, L., Petrik, M., Holland, G., Appel, K., Nüssler, A., Neuhaus, P. und Gerlach, J. (2000). Leberzellkultur in Bioreaktoren für in vitro Studien zum Arzneimittelmetabolismus als Alternative zum Tierversuch (Liver cell culture in bioreactors for in vitro drug studies as an alternative to animal testing). ALTEX 17, 3-10.

\section{Correspondence to}

PD Dr. Franz P. Gruber

FFVFF

Hegarstr. 9

P.O. Box 1766

CH-8032 Zürich

Switzerland

E-mail: fpg@ffvff.ch 